\title{
RETHINKING THE ECONOMIC BASIS OF THE STANDARD OIL REFINING MONOPOLY: DOMINANCE AGAINST COMPETING CARTELS
}

\author{
GEORGE L. PRIEST ${ }^{*}$
}

\begin{abstract}
The success of the Standard Oil monopoly is not well understood. Standard Oil first developed a monopoly over the refining of crude oil, though later extended its control to gathering pipelines, later still to trunk pipelines (from the western Oil Regions to East Coast ports) and, even later, expanded operations to include oil production (drilling) and retail sales at the time the Supreme Court ordered its dissolution over 100 years ago, in 1911 .

Though there are several journalistic exposés of Standard Oilincluding Henry Demarest Lloyd and Ida Tarbell, as well as business histories-none are fully explanatory. The currently dominant theory of Standard Oil's success is by Elizabeth Granitz and Benjamin Klein who assert that Standard Oil was chosen by oil shippers, the railroads, to police a railroad cartel. According to Granitz and Klein, the railroads split with Standard Oil the profits from cartelization of the crude and refined oil industry.

* Edward J. Phelps Professor of Law and Economics and Kauffman Distinguished Research Scholar in Law, Economics, and Entrepreneurship, Yale Law School. I am grateful to Jonathan Kandelshein for excellent research assistance and to the Milton and Miriam Handler Foundation for a grant to Yale Law School for support for this work. I am also grateful to Alvin K. Klevorick, Bruce Ackerman, Robert Ellickson, Benjamin Klein, Claire Priest, Nicholas Priest, Norman Silber and to participants in the Yale Law School Faculty Workshop for comments on an earlier draft.
\end{abstract}


This Article challenges that explanation, claiming that there were attempts made to cartelize at all levels of the oil industry-producers, gathering pipelines, refiners, and railroads. There are good economic reasons that explain why Standard Oil, a refiner at the remote western location of Cleveland, acquired most of the pipelines and secured a monopoly against the producers and the railroads.

\section{INTRODUCTION: THE IMPORTANCE OF UNDERSTANDING STANDARD OIL'S REFINING MONOPOLY}

The success of Standard Oil in creating a near-monopoly over the refining of crude oil between 1872 and 1879 is not completely understood. The industrial history of the period is complicated. Standard Oil's growth built on an extraordinary increase in aggregate demand for what was then the principal crude oil product-refined kerosene-used as an illuminant before the invention of the electric light bulb. During these years, most refined kerosene produced in the United States was exported, chiefly to Europe. Because the oil fields generating the crude oil for refining were located exclusively in northwest Pennsylvania, far from Atlantic ports, transport of oil to the East Coast was a significant component of ultimate costs. At various points during the growth of Standard Oil, combinationsthat is, cartels-were attempted to control, in rough progression from production to consumer: (1) crude oil production among oil drillers; (2) the collection of crude oil from wells to local railroads, ultimately in local pipelines ("gathering lines") to transport oil to railroads and refiners; (3) the process of refining crude oil into kerosene; and (4) the transport to the East Coast of crude oil to be refined, and of kerosene that had been refined in the West, for East Coast consumption and for eventual export. As shall be explained, the firms in each of these stages of production attempted to cartelize to maximize revenues from the oil business. Of these combinations, only the Standard Oil monopoly of refining - the third stage of the process-proved of long-standing success. The economic question is why?

Understanding the economics of the creation and maintenance of the Standard Oil refining monopoly is important both as a matter of industrial organization and for current antitrust law. The 1911 Supreme Court opinion affirming the dissolution of Standard Oil ${ }^{1}$ remains iconic: first, because it embodies the Court's first adoption of the Rule of Reason as the principal

1. Standard Oil Co. v. United States, 221 U.S. 1 (1911). 
standard for Sherman Act interpretation, ${ }^{2}$ a standard that has become even more central to antitrust doctrine over the past four decades; second, because it represents the first major implementation of the Act by the Court to dissolve an existing monopoly which, at the time, was the largest and most successful firm in American history.

Of course, there have been many changes in antitrust doctrine since 1911 , especially with respect to the evaluation of monopolies. In the Standard Oil opinion, the central issue before the Court was not the evaluation of the economic effects of the Standard Oil monopoly itself, ${ }^{3}$ but the determination of whether there were then-current grounds for antitrust liability (the prosecution was filed in 1906) ${ }^{4}$ given the fact that the Standard Oil monopoly had been formed in the 1870 s, more than a decade before the prohibition of monopolization under the Sherman Act. ${ }^{5}$ The Court held Standard Oil guilty of monopolization chiefly on the basis of post-Sherman Act corporate reorganizations of the pre-Sherman Act monopoly, which the Court held to constitute continuing exclusionary acts. $^{6}$

In the most prominent of later monopolization cases, the Court attempted to distinguish monopolies created by what might be regarded as exclusionary practices versus those created on the merits: exonerating the merger-to-monopoly in the steel industry in U.S. Steel because it could not identify any exclusionary behavior; 7 but finding a violation by Alcoa (confusingly) for practices that appear to have consisted principally of expanding demand and supply of the product. $^{8}$

2. See id. at 66 (" $[\Pi] \mathrm{n}$ every case where it is claimed that an act or acts are in violation of the statute the rule of reason, in light of the principles of law and the public policy which the act embodies, must be applied."). For a discussion of how the Standard Oil opinion influenced the creation of the Federal Trade Commission and the enactment of the Clayton Act, see G.L. Priest, Standard Oil, the Origins of Dual Antitrust Jurisdiction in the U.S., and the Modern Justification for United Enforcement, CONCURRENCES (forthcoming 2012). For a discussion of the constitutional implications of the opinion, see OWEN M. FISS, TROUBlED BEGINNINGS OF THE MODERN STATE, 1888-1910, at 107-54 (1993).

3. At the time of the Supreme Court's opinion in the case, Standard Oil's market share of refined oil was roughly 64 percent, a questionable monopoly. Leslie D. Manns, Dominance in the Oil Industry: Standard Oil from 1865 to 1911, in MARKET DOMINANCE: HOW FIRMS GAIN, HOLD, OR LOSE IT AND THE IMPACT ON ECONOMIC PERFORMANCE 32 (David I. Rosenbaum ed., 1998).

4. Standard Oil, 221 U.S. at 31.

5. There were constitutional dimensions to this question, implicating the Supreme Court's commitment to the right to own property. See FISS, supra note 2.

6. Id. at 75-77 (discussing Standard Oil's consolidation of stock in its New Jersey corporation as a means of trying to monopolize the market).

7. See United States v. U.S. Steel Corp., 251 U.S. 417, 455-57 (1920).

8. United States v. Aluminum Co. of Am. (Alcoa), 148 F.2d 416, 432 (2d Cir. 1945). 
In more recent years, however, the Court has refined its analysis of when monopolies should be held to have violated the Sherman Act. For example, in Grinnell, the Court announced what has become the principal standard for evaluating claims of monopolization,

The offense of monopoly under $\S 2$ of the Sherman Act has two elements: (1) the possession of monopoly power in the relevant market and (2) the willful acquisition or maintenance of that power as distinguished from growth or development as a consequence of a superior product, business acumen, or historic accident. ${ }^{9}$

Given this modern standard, it is important to understand whether the creation of the Standard Oil monopoly derived from the business acumen of its principal founder, John D. Rockefeller, and his associates, or from other competitive advantages, versus from ulterior practices antithetical to competition.

More recently yet, the Court has seemed to acknowledge and perhaps, embrace the values of monopolization as a spur to competitive innovation. In the 2004 case, Verizon Communications v. Law Offices of Curtis $V$. Trinko, $L L P{ }^{10}$ the Court, after quoting the Grinnell passage dealing with business acumen, quite remarkably endorsed possession of monopoly,

The mere possession of monopoly power, and the concomitant charging of monopoly prices, is not only not unlawful; it is an important element of the free-market system. The opportunity to charge monopoly pricesat least for a short period-is what attracts "business acumen" [the Grinnell standard] in the first place; it induces risk taking that produces innovation and economic growth. To safeguard the incentive to innovate, the possession of monopoly power will not be found unlawful unless it is accompanied by an element of anticompetitive conduct. ${ }^{11}$

Considering this standard, it is an important historical issue to determine how Standard Oil created its monopoly. Should the monopoly be condemned-as the Court concluded in 1911 - or saluted for taking risks to produce innovation and economic growth?

\section{PREVIOUS UNDERSTANDINGS OF THE STANDARD OIL REFINING MONOPOLY}

Standard Oil's predominance has generated many efforts to describe and explain the Company's growth. Early, largely journalistic, treatments

\footnotetext{
9. United States v. Grinnell Corp., 384 U.S. 563, 570-71 (1966).

10. Verizon Commc'ns Inc. v. Law Offices of Curtis V. Trinko, LLP, 540 U.S. 398 (2004).

11. Id. at 407 .
} 
by Henry Demarest Lloyd ${ }^{12}$ and Ida Tarbell ${ }^{13}$ condemn the Company. Lloyd's criticism is a diatribe against the size of the Company, ${ }^{14}$ irrelevant according to the Court's current treatment of monopolization. Tarbell's essays are similar, though they incorporate a theory that Standard Oil used rebates on oil shipments gained from the railroads to underprice its competitors through predatory pricing; ${ }^{15}$ if true, these practices might well be regarded as exclusionary today.

In an important article in 1958, John McGee claims to refute Tarbell's predatory pricing theory by explaining the economic illogic of the practice (drawing from the ideas of Aaron Director) and by showing that many of Standard Oil's acquisitions of competing refiners were achieved, not by underpricing them to drive them out of business, but by sharing with them the monopoly returns that resulted from the combination. ${ }^{16}$ The objective of McGee's article was only to disprove Tarbell's predatory pricing explanation; he expressly declines to comment (incredibly) on the competitive merits of the creation of the Standard Oil monopoly or of its dissolution. ${ }^{17}$

Several subsequent commentators conclude that the Standard Oil monopoly was obtained by variants of the standard announced in Grinnell of "business acumen" or "superior product."18 Allan Nevins's biography of Rockefeller attributes the success of Standard Oil to Rockefeller's expertise in management. ${ }^{19}$ Nevins's treatment, however, while full of interesting

12. See HeNRy DeMarest Lloyd, WEALTH AGainst COMMONWEAlth (1894).

13. See IDA M. TARBEll, THE History of THE STANDARd Oll COMPANY (1924).

14. LLOYD, supra note 12 , at 8 . ("It [the oil trust] is the most successful of all the attempts to put gifts of nature, entire industries, and world markets under one hat.").

15. TARBELL, supra note 13 , at 71 (describing the difference between Standard and a competitor-Standard being able to ship for $\$ 0.65, \$ 0.55$, and $\$ 0.35$ while rivals could ship, at best, for $\$ 0.80$ or $\$ 0.70$ per barrel).

16. John S. McGee, Predatory Price Cutting: The Standard Oil (N.J.) Case, 1 J.L. \& ECON.137 (1958). Recently, James Dalton and Louis Esposito claim to refute McGee based on more modern economic analysis of predatory pricing. After reviewing the Standard Oil record, they claim that Standard Oil might have engaged in predatory pricing, though they cannot confirm that Standard Oil's practices would lead to liability under current law. See generally James A. Dalton \& Louis Esposito, Predatory Price Cutting and Standard Oil: A Re-Examination of the Trial Record, 22 RES. IN L. AND ECON. 155 (2007). McGee only examined the record in the Standard Oil Supreme Court case, which did not include evidence regarding Standard Oil's acquisition of refiners in the 1870 s, a point made by Benjamin Klein, The "Hub-and-Spoke" Conspiracy that Created the Standard Oil Monopoly, 85 S. CAL. L. REV. 459, 496 n.138 (2012). Dalton and Esposito, similarly, looked only at the Standard Oil Supreme Court record.

17. See McGee, supra note 16, at 169 ("The issue of whether the monopoly should have been dissolved is quite separate.").

18. United States v. Grinnell Corp., 384 U.S. 563, 571 (1966).

19. See generally, 1 ALLAN NEVINS, STUDY IN POWER: JOHN D. ROCKEFELLER, INDUSTRIALIST 
details of Rockefeller's career, does not pretend to perform an economic analysis of Standard Oil's predominance. There are other business history discussions in the same vein. ${ }^{20}$

With respect to the economic analysis of the creation of the Standard Oil monopoly, Lester Telser, in a brief treatment in a book more generally addressing the theory and operation of cartels, concludes that Standard Oil succeeded in lowering the price of refined oil to the benefit of consumers. ${ }^{21}$ More recently yet, though even more briefly, Alfred Chandler concludes that the Standard Oil monopoly resulted from the exploitation of economies of scale and from the coordination of the flow of materials from producer to consumer that led to substantial declines in the average cost of refined oil production. ${ }^{22}$ As mentioned, however, Nevins and other business history treatments, though full of details, ignore economic analysis. The brief discussions of Telser and Chandler, while economically skilled, largely abstract from the specific facts of the growth of Standard Oil. Very recently, in 2011, Michael Reksulak and William F. Shughart II argued that the various discounts that Standard Oil received from the railroads represented appropriate compensation for value offered from Standard Oil's investment in rolling stock, warehouses, and terminals. ${ }^{23}$ This argument, however, does not provide a careful calculation of these benefits or an explanation as to why these investments were made by Standard Oil, instead of by the railroads themselves.

By a large measure, the most sophisticated economic discussion of the creation of the Standard Oil refining monopoly is a 1996 article by Elizabeth Granitz and Benjamin Klein, supplemented by Klein's article in this volume. ${ }^{24}$ Granitz and Klein explain Standard Oil's acquisition of its refining monopoly as deriving from a plan to stabilize a railroad cartel

AND PHILANTHROPIST (1953) (discussing Standard Oil and Rockefeller's success).

20. See e.g., Harold F. Williamson \& ARNold R. DaUm, THE AMERICAN Petroleum INDUSTRY: The AGE OF Illumination, 1859-1899 (1959); Ralph W. Hidy \& MURIEl E. Hidy, PIONEERING IN BIG BusINESS: 1882-1911 xxi (1955); Hidy and Hidy was commissioned by Standard Oil, HIDY \& HIDY, supra, at xix; Williamson and Daum was commissioned by the American Petroleum Institute, WILLIAMSON \& DAUM, supra, at ix.

21. Lester G. Telser, A THEORy OF Efficient CoOperation and COMPETITION 36-41 (1987).

22. Alfred D. Chandler, JR., SCALE and SCOPE: The Dynamics of InduStrial CaPitalism 24-25 (1990).

23. Michael Reksulak \& William F. Shughart II, Of Rebates and Drawbacks: The Standard Oil (N.J.) Company and the Railroads, 38 REV. INDUS. ORG. 267, 269, 280 (2011).

24. See Elizabeth Granitz \& Benjamin Klein, Monopolization by "Raising Rivals' Costs": The Standard Oil Case, 39 J.L. \& ECON. 1 (1996); Klein, supra note 16. Benjamin Klein is a dear co-author of mine. 
devised by the three railroads that transported oil to the East Coast for export. ${ }^{25}$ According to Granitz and Klein, the oil transporting railroads had made earlier attempts to cartelize, but these attempts had failed on account of cheating by one or another railroad. In 1871, as the oil refining business was developing, the railroads concocted a plan according to which they would appoint the largest oil refiners in each of the various oil refining cities to maintain and police their cartel. ${ }^{26} \mathrm{By}$ this agreement, the appointed refiners would guarantee specific percentages of their shipments to the respective railroads. ${ }^{27}$ This guaranty allowed the railroads to increase general shipping rates. ${ }^{28}$ The policing refiners were called "eveners" for their role in allocating oil shipments among the railroads. ${ }^{29}$ As compensation for this service, the eveners would receive both rate discounts on their own shipments, rebates, and equivalent payments on the shipments of their competitors, called drawbacks. ${ }^{30}$ Because, by this agreement, the railroads had to pay drawbacks to the eveners on shipments by the competing refiners ("the independents"), the railroads had no incentive to cheat on the cartel agreement by offering discounts to the independents. ${ }^{31}$ Thus, the railroads would be assured higher general rates, while the eveners would benefit from differentially lower transport costs than their competitors.

According to Granitz and Klein, the principal ambition of this agreement was to shore up the cartel agreement of the railroads. Standard Oil and the other evener refiners became "[c]artel [r]ingmaster[s].",32

25. Granitz \& Klein, supra note 24 , at 2.

26. Id. at 8 .

27. Id.

28. Id. at 10

29. Id. at 9.

30. Granitz and Klein distinguish "rebates" as discounts on a given shipper's own shipments from "drawbacks" as railroad payments of amounts for shipments on other shipper's shipments. Granitz \& Klein, supra note 24, at 9-10. Most other treatments do not employ the terms in this way. To most, rebates and drawbacks refer to railroad discounts in general, differentiated by when the discount was paid: rebates given at shipment; drawbacks given at some later time. For a discussion of this terminology, see Rolland HARPER MAYBEE, RAILROAD COMPETITION AND THE OIL TRADE, 18551873 , at 308-311 (1940).

31. Granitz \& Klein, supra note 24 , at 10 n.29.

32. Id. at 26 n.64 (quoting Thomas G. Krattenmaker \& Steven C. Salop, Anticompetitive Exclusion: Raising Rivals' Costs to Achieve Power Over Price, 98 YALE L.J. 209, 240 (1986); Klein, supra note 16, at $461,487-91$. Klein adjusts the analysis slightly by characterizing the agreement not as "cartel ringmaster," but as a "hub-and-spoke conspiracy." Klein, supra note 16, at 459 . A hub-andspoke conspiracy is one in which a firm ("hub") dealing with separate firms at a different level of production who are competitors among each other ("spokes") engages in practices that cartelize the competing spoke-firms with gains somehow shared with the hub firm. Id. at 129-33. This characterization is not significantly different from the "cartel ringmaster" explanation. 
Incidentally, however, the agreement, by creating a substantial differential in transport costs as between the eveners (including Standard Oil) and the independents put the independents at a sharp competitive disadvantage. ${ }^{33}$ This disadvantage enabled Standard Oil to buy up the independents at distress prices; first in Cleveland in 1872 almost immediately after entering the agreement with the railroads and later in other cities, creating the Standard Oil refining monopoly. ${ }^{34}$ Thus, according to Granitz and Klein, the Standard Oil monopoly was attained by "raising rivals' costs" - that is, the transport costs of its competitors through deals with the railroadsallowing Standard Oil to buy up all of the competing refiners at distress prices. ${ }^{35}$

From an economic standpoint, this explanation is similar to, but somewhat the reverse of, Tarbell's predatory pricing theory. ${ }^{36}$ Standard Oil forced the independents out of the market by under pricing them based on its differential railroad rebates and drawbacks, not by Standard Oil selling below cost as in typical predatory pricing-Tarbell's explanation. Ultimately, the independents were driven out because the railroads were charging them comparatively higher transport rates. ${ }^{37}$

The central point of the Granitz-Klein explanation of the Standard Oil refining monopoly is the counter-intuitive explanation that Standard Oil, an oil refiner and a customer of railroads, conspired with the railroads to monopolize the oil industry. Granitz and Klein repeatedly emphasize that the monopoly power over oil derived from the railroads-against which entry was difficult-rather than from Standard Oil as a refiner-against which entry was easy. ${ }^{38}$

The Granitz-Klein theory of the emergence of the Standard Oil monopoly remains the dominant economic explanation today. Much of its strength derives from its detailed examination of the history of the development of Standard Oil; indeed, much more detailed than any other economic discussion.

There exist, nevertheless, two conceptual and factual complications regarding the Granitz-Klein theory. First, the historical facts of the consolidation of oil refining are substantially more ambiguous than the

33. Granitz \& Klein, supra note 24 , at 14.

34. Id. at 14 .

35. Id. at 23 .

36. See supra notes 13,15 and accompanying text.

37. Granitz and Klein acknowledge that their theory is similar to Tarbell's theory. Granitz \& Klein, supra note 24 , at 3 .

38. Id. at 23-24, 26, 27 \& n.64. 
Granitz-Klein theory admits. Granitz and Klein account principal predominance to the 1871 South Improvement Company agreement, which is well known because it was memorialized and, when publicized, became highly controversial..$^{39}$ The South Improvement Company agreement between the three railroads and the eveners set forth the allocation of transport shares among the railroads (which looks like a typical cartel agreement) and provided for rebates and drawbacks to Standard Oil and the other eveners. ${ }^{40}$ Granitz and Klein credit the South Improvement Company agreement for Standard Oil's success chiefly on the basis of timing. ${ }^{41}$ Standard Oil acquired most of the independent refiners in Cleveland within months of this agreement in $1871 ;^{42}$ some years later, Standard Oil acquired refiners in other cities.

The Granitz-Klein point about the timing of Standard Oil's Cleveland acquisitions is surely correct. But the South Improvement Company agreement never went into effect; ${ }^{43}$ the conclusion that all Cleveland refiners sold out to Standard Oil on the prospect of the agreement's success remains speculative. In fact, the revelation of the agreement led to an immediate revolt by crude oil producers-forming the Petroleum Producers' Union (a cartel that succeeded other efforts to cartelize producers) that organized what appears to have been an effective boycott of the evener refiners. ${ }^{44}$ The Petroleum Producers' Union doomed the South Improvement Company agreement leading the railroads to quickly withdraw from it; ultimately, to a settlement between the crude oil producers and the railroads restoring shipment rates to pre-agreement levels that were substantially less than those announced in the agreement; ${ }^{45}$ and to the State of Pennsylvania revoking the South Improvement Company's charter shortly thereafter. ${ }^{46}$

These facts complicate the analysis substantially. After the formation

39. Granitz \& Klein, supra note 24 , at $9-10$. The episode remains a central story of Robber Baron history. See MATTHEW JosephSON, THE RoBber BARONS 159-63 (1934) (discussing the widespread public outcry and reaction against news of the 1872 agreement between Standard Oil and the railroads to dominate the oil industry).

40. Granitz \& Klein, supra note 24, at 9-10.

41. Id. at 43-44 ("The most convincing evidence that Rockefeller created market power in the petroleum industry by cartelizing transportation is ... the detailed behavioral evidence we have presented. The evidence includes the timing and completeness of Standard's initial consolidation in Cleveland after the formation of the South Improvement Company ....").

42. Id. at 15 .

43. Id. at 14 .

44. Id. at 14-15.

45. WILLIAMSON \& DAUM, supra note 20, at 351-52.

46. Granitz \& Klein, supra note 24 , at 15. 
of the Petroleum Producers' Union, there were three potential monopolies or cartels involved in the process: (1) crude oil producers through the Petroleum Producers' Union; (2) refiners, as Standard Oil was acquiring its competitors; and (3) the railroads. In addition, though not carefully discussed by Granitz and Klein, ${ }^{47}$ there was a fourth attempted cartel: (4) pipelines gathering crude oil from wells to deliver to railroads or to refiners. Analysis of the economics of the industry becomes much more complicated.

The second complication is the effect of the railroads' agreement. The agreement not only enabled Standard Oil to create a monopoly over oil refining, but also to create a monopsony with respect to the purchase of crude oil from producers and to the purchase of transport services from the railroads. Granitz and Klein do not carefully discuss monopsonization by Standard Oil or its implications. ${ }^{48}$ Moreover, they do not explain why an emerging dominant refiner such as Standard Oil would act to aid in the cartelization of the railroads. At best, according the Granitz-Klein theory, there is a complicated interactive bilateral monopoly relationship between Standard Oil and the railroads that remains to be fully explored.

Part III will more carefully describe the Granitz-Klein explanation of the growth of the Standard Oil monopoly, but also suggest some problems with their theory. Part IV will present an alternative theory. At base, it proposes that all of the respective firms involved in the production and delivery of refined oil separately sought, at each stage, to form cartels or monopolies to control the oil trade. Before the Sherman Act was an era in which firms at different levels of production sought the advantage of creating horizontal cartels and battled with firms at different levels of production over which cartel would dominate.

In this context, Rockefeller and his associates saw the advantage of monopolizing oil refining. Quite in opposition to the Granitz-Klein explanation, however, Standard Oil and the other eveners did not facilitate a railroad cartel, the "cartel ringmaster" theory. Instead, Standard Oil quickly and intentionally gained a monopoly over refining and, simultaneously, a monopsony over both the purchase of crude oil and of railroad transport of crude and refined oil. Again, in contrast to the GranitzKlein theory, the railroads did not dominate monopolization of the industry. Instead, they eventually were the victims, as Rockefeller and Standard Oil created their refining monopoly-monopsony and executed the

47. Id. at $35-36$.

48. See id. at 39-42. 
market power that they had created. There are good economic reasons explaining why, of all of the attempted combinations at various stages in the industry, the monopoly over refining would prevail over attempted cartels of oil production; of gathering pipelines (though, as will be seen, a complicated question, leading Standard Oil to aggressively acquire gathering pipelines) $;{ }^{49}$ and of the railroads.

It must be admitted, however, that there are many gaps in the empirical record of the oil industry in the 1870 s and, thus, many potential gaps in the theory. The detailed examination by Granitz and Klein has substantially advanced the understanding of the industry. Nevertheless, quite to my surprise in entering this project, the data describing the progress of the industry are extraordinarily spotty. ${ }^{50}$

The Supreme Court's decision in 1911 to dismember Standard Oil is related to this point. ${ }^{51}$ The Court's ruling that dissolved Standard Oil ended substantial interest in the Company. Tellingly, most subsequent business histories of Standard Oil were subsidized by the Company or related entities and did not closely examine the creation of the refining monopoly. One hundred years later, an understanding of the economic development of the industry and of Standard Oil's refining dominance remains an aspiration.

\section{THE GRANITZ-KLEIN THEORY OF THE STANDARD OIL REFINING MONOPOLY}

Granitz and Klein attempt to explain how Standard Oil grew from Rockefeller's first involvement in oil refining in 1863 in Cleveland, to Standard Oil's monopoly of Cleveland refineries by 1872, and then to its national near-monopoly, possessing 90 percent of U.S. oil refining by 1879. ${ }^{52}$ Section A describes the conditions in the refined oil market before Standard Oil's acquisition of the independent refineries. Section B presents the Granitz-Klein theory of the creation of the refining monopoly. Section $\mathrm{C}$ discusses problematic features internal to the Granitz-Klein theory. Part IV presents a different theory.

49. See id. at 35 (providing examples of Standard Oil's efforts to acquire pipelines).

50. As an example, I have not been able to acquire data on the shipment east of crude versus refined oil from the Oil Regions (the oil fields in western Pennsylvania, see infra Part IV.A.) and connected cities. This is a potentially important datum that would add to the understanding of the refiners' actions. There are many other gaps in the historical record.

51. Standard Oil Co. v. United States, 221 U.S. 1 (1911).

52. Granitz \& Klein, supra note 24 , at 2. 


\section{A. THE DEVELOPMENT OF THE OIL INDUSTRY IN THE UNITED STATES AND ROCKEFELLER'S BEGINNINGS}

Standard Oil achieved its national near-monopoly of refined crude oil before the invention of the automobile and the development of gasoline as a dominant fuel for internal combustion engines. Standard Oil's chief product, and that of other refineries (though there were other less significant byproducts ${ }^{53}$ ), was kerosene refined from crude oil used for interior and exterior lighting, a superior illuminant to coal-oil (oil distilled from hard coal), whale oil, and tallow candles prior to the invention of the light bulb and the development of commercial electric service. ${ }^{54}$

The demand for kerosene increased substantially during the 1860 s and $1870 \mathrm{~s} .{ }^{55}$ Until the development of oil fields in Russia in the late nineteenth century and further international discoveries, the United States was the principal worldwide source of crude and refined oil. ${ }^{56}$ From the mid-1860s to the early 1870 s, total U.S. oil refining capacity increased by four times: from 11,680 barrels per day in $1864-1865$ to 47,600 barrels per day in $1872-1873 .^{57}$ The large majority of refined oil was exported, mostly to Europe, whose aggregate economy was larger than the U.S. economy, and whose demand for kerosene was substantially greater. ${ }^{58}$ From 1873 to $1875,75.1$ percent of the aggregate U.S. production of refined illuminating oil was exported abroad..$^{59}$

As Granitz and Klein ably explain, because of the distance of the oil

53. See infra note 59 .

54. WilliamsON \& DAUM, supra note 20 , at 29-42 (tracing the gradual improvement in illumination products from the early 1700 s to the 1800 s); id.at $371-72$ (noting that, by 1873 , kerosene was "firmly established as a leading illuminant").

55. Id. at 521-22.

56. Id. at 518 .

57. Id. at 291. Note, that it appears that there were many periods of local overproduction. As a consequence, it is important to distinguish, where possible, between measures of refined oil capacity and refined oil output. For many of the time periods discussed, there are not reported measures of both capacity and output. It has become an industry standard that a barrel of oil equals 42 gallons. Id; Granitz \& Klein, supra note 24 , at 20 n.53. Nevertheless, there are references to 45 - and 47-gallon barrels, TARBELL, supra note 13, at 283; and 40-gallon barrels, WILLIAMSON \& DAUM, supra note 20, at 740 app. C.

58. Granitz \& Klein, supra note 24 , at 3.

59. WILLIAMSON \& DAUM, supra note 20, at 498. Of total exports during the period, 1873-1875, illuminating oil-kerosene-dominated, constituting 87 percent. Of oil products other than refined kerosene, crude oil constituted 7 percent of exports; refined naptha-benzene (gasoline), 5 percent; and lubricating oils, 0.5 percent. $I d$. (presenting table from which calculations were derived). As shall be seen, these percentages would change over time, possibly reflective of the Standard Oil refining monopoly. 
fields in western Pennsylvania, called the "Oil Regions," to East Coast ports, the transport of refined and crude oil was an important element of costs. ${ }^{60}$ Transport by railroad dominated, though there was the possibility of shipment by water during summer months from ports on Lake Erie (including Cleveland) to Buffalo, through the Erie Canal to Albany, and down the Hudson River to New York, although water shipment only accounts for a small portion of shipments. ${ }^{61}$ Granitz and Klein estimate that railroad costs constituted, on average, 38 percent of oil export prices. ${ }^{62}$

At the time of the creation of the Standard Oil monopoly, there were three railroad systems competing for oil transport to the East Coast: (1) the Pennsylvania Railroad system, which connected Pittsburgh ${ }^{63}$ to Philadelphia and (with its affiliate, the Empire Transport Company) to New York; (2) the Erie Railroad system, which connected the Oil Regions (with its affiliate, the Atlantic \& Gulf Western) directly east to New York as well as west to Cleveland and back to New York; and (3) the New York Central Railroad system, which connected the Oil Regions north and east to Buffalo, to Albany, and to New York as well as west to Cleveland and back to New York. ${ }^{64}$ Standard Oil was headquartered in Cleveland, and so, in its early years before its acquisitions of refiners in other cities, was in a position to ship on the Erie and the New York Central railroad systems or by water through the Erie Canal--a fact alluded to, but not emphasized by, Granitz and Klein ${ }^{65}$-though I think important to explain the ultimate success of Standard Oil.

Rockefeller worked for a commodity merchant company-chiefly a brokerage-in Cleveland when the first drilling for crude oil was

60. Granitz \& Klein, supra note 24 , at $4-6$.

61. WILlIAMSON \& DAUM, supra note 20, at 195. In 1871,13 percent of 1.75 million barrels of oil was shipped east from Cleveland along the water route through the Erie Canal. Id. at 300 . The percentage of actual shipments by boat may be underdescriptive of the competitive influence of water transport. Standard Oil obtained lower rates for summer than for winter transport from both the New York Central and the Erie railroads. Granitz \& Klein, supra note 24, at 17.

62. Granitz \& Klein, supra note 24 , at $5 \mathrm{n} .11$. Their footnote does not clearly distinguish between crude and refined oil which requires further study.

63. Pittsburgh was the earliest oil refining center, as the largest city down the Allegheny River and near coal supplies necessary for refiners. In the early years, crude oil was either carted or floated down rivers in the Oil Regions to the Allegheny River and then shipped downstream to Pittsburgh for refining. WILliAMSON \& DAUM, supra note 20, at 165-69. As an example of the magnitude of transport, Williamson and Daum claim that, by 1865 , there were 2000 boats engaged in oil transport from the Oil Regions to Pittsburgh. $I d$. at 168.

64. Granitz and Klein present a helpful map of these competing routes. Granitz \& Klein, supra note 24, at 4. See also MAYBEE, supra note 30, at 127-28.

65. Granitz \& Klein, supra note 24 , at 6. 
successful in the nearby Oil Regions in $1859 .{ }^{66} \mathrm{He}$ joined a company building an oil refinery in $1863 .{ }^{67}$ In 1865 , Rockefeller-then age 26(with some associates) bought the company out, in some discussions, because he saw the potential growth of oil refining and wanted to redirect the company's focus to that product. ${ }^{68}$ At the time, the company's oil refinery was the largest in Cleveland, ${ }^{69}$ though small on a national scale because Cleveland was a relatively small refining center. The Company was incorporated as the Standard Oil Company in $1870 .^{70}$

\section{B. THE CREATION OF THE STANDARD OIL REFINING MONOPOLY}

Granitz and Klein attribute Standard Oil's ability to gain a monopoly in oil refining to a plan devised by an executive of one of the three railroad systems. ${ }^{71}$ Railroads possess natural monopoly characteristics: high fixed costs and declining average costs. This was well known at the time and much discussed as the "railroad problem."72 Given these cost functions, the three railroad systems faced severe competitive pressures to gain transport custom at any price above or even equal to marginal costs though, of course, marginal cost pricing was unsustainable in the long run. These three railroads (like other railroads at the time) had attempted cartels, but the cartel agreements had broken down repeatedly. These breakdowns were caused by individual railroads violating the cartel agreements by giving discounts or rebates to obtain greater freight volume. ${ }^{73}$

In 1871, an executive of the Pennsylvania Railroad devised a plan to reduce the problem of cheating on railroad cartel agreements. ${ }^{74}$ The plan was to be consummated by creating a new corporation called the South Improvement Company. ${ }^{75}$ This company was to be owned, as Granitz and Klein tell it, by a group of oil refining companies, one from each of the major refining centers: Pittsburgh, Cleveland, Philadelphia, and New

\footnotetext{
66. See NEVINS, supra note 19 , at 20-21.

67. See id. at 23.

68. Id. at 34 .

69. Id. at 37 .

70. Id. at 83 .

71. Granitz \& Klein, supra note 24 , at 9 n. 26 .

72. Granitz and Klein have an excellent discussion of this issue. Id. at $8 \&$ n.23, For another excellent discussion, see HERBERT HOVENKAMP, ENTERPRISE AND AMERICAN LAW: 1836-1937, at $141-48$ (1991).

73. Granitz \& Klein, supra note 24, at 8.

74. Granitz and Klein emphasize that the plan was originated by a railroad executive. Id. at 9 n.26.

75. Id. at 9.
} 
York-to be selected by the railroads. ${ }^{76}$ These refiners, through the South Improvement Company, were to enter contracts with the three previously competing railroads allocating among the railroads defined shares of oil shipments to the East Coast: 45 percent to the Pennsylvania Railroad and 27.5 percent each to the Erie and New York Central railroads. ${ }^{77}$ The refiners who subscribed to the South Improvement Company were called the eveners because their role was to allocate oil shipments among the three railroads.

As Granitz and Klein explain it, this agreement enabled the railroads to cartelize by fixing substantially higher shipment rates for oil. ${ }^{78}$ In return for the refiners' role in allocating oil shipments, the railroads promised to pay the eveners a rebate from basic shipping rates on their own oil shipments plus a drawback payment on the shipments of the independents and of producers. ${ }^{79}$ Thus, the railroads would increase shipment rates for the independents and producers, while the eveners would obtain rebates on their own shipments and drawbacks on the shipments of their competitors and the producers. The railroads' agreement to pay the South Improvement Company drawbacks on the shipments of the independents and producers reduced each railroad's incentive to cheat on the cartel price by giving secret deals to them. ${ }^{80}$

The rebates and drawbacks gave the eveners a substantial shipping cost advantage over the independents. According to Granitz and Klein, the independents, faced with the substantial differential in shipping costs against the South Improvement Company eveners, quickly recognized that they had no possibility of competing with them. ${ }^{81}$ Standard Oil was the evener refiner in Cleveland; its competitors, the independents, could not compete and had to sell out. Within three months of the South Improvement Company agreement, Standard Oil was successful in

76. Id. The South Improvement Company agreement, however, was not exactly drafted as Granitz and Klein describe it. The shareholders of the company were individual executives, not the refining companies themselves, and there was not equal representation among the four refining cities. See infra note 158 and accompanying text. How it actually would have operated is unclear.

77. Granitz \& Klein, supra note 24 , at 9.

78. See id. at 10 ("[T]he rates proposed by the railroads in their agreements with the South Improvement Company represented a huge increase over preexisting rates.").

79. Id. at 9-10.

80. Id. Klein, supra note 16, at 469-70. Though not explained by Granitz and Klein, the gain from cheating was reduced because of the agreement to pay drawbacks, but not eliminated; that is, where the higher rate to an independent, less the drawback, still exceeded the marginal cost of transport, though this point depends on the auditing success of the South Improvement Company.

81. Granitz \& Klein, supra note 24 , at 15. 
acquiring all competing refiners in Cleveland at distress prices, ${ }^{82}$ acquisition prices reduced, according to Granitz and Klein, on account of the shipping cost differential imposed by the South Improvement Company's agreement with the three railroads. ${ }^{83}$

Differential transport costs as between the eveners, including Standard Oil, and the independents are central to the Granitz-Klein explanation of Standard Oil's acquisition of its refinery monopoly. ${ }^{84}$ Granitz and Klein rebut the McGee explanation of Standard Oil's acquisition by profitsharing by arguing that the preferable position of an independent was not to sell out to Standard Oil as it was enlarging its market position, but to remain independent and to charge just less than the monopoly price, under the umbrella of the Standard Oil monopoly. ${ }^{85}$ Yet, according to Granitz and Klein, given the magnitude of the combined rebates and drawbacks, even if an independent were able to charge just less than the monopoly price, it would be unable to successfully compete because of the transport cost differential against the eveners. ${ }^{86}$

Granitz and Klein emphasize that Standard Oil acquired the independents at distress prices as showing the effectiveness of the South Improvement Company agreement. As an example, they quote George $\mathrm{O}$. Baslington, an executive of a refiner who sold out to Standard Oil in February 1872, as stating,

[Our company] sold [our] works to the Standard Oil Company, which were on the day of the sale worth at least $\$ 100,000$, for $\$ 45,000$ because that was all they could obtain for them, and works too which in cash cost them not less than $\$ 76,000$, and which with a fair competition would have paid them an income of not less than 30 per cent. per annum on investment. $^{87}$

Most significant to Granitz and Klein is the timing of Standard Oil's

82. Id. at $14-15$.

83. See id. (discussing the independents' willingness to sell at distress prices because the probability of the price squeeze was non-negligible). Granitz and Klein predict that the distress price at which independents sold out to Standard Oil equaled market price less the expected value of future drawbacks on their shipments, id. at $16 \mathrm{n} .39$, a theoretical, not an empirically demonstrated, point.

84. Id. at 1,35 .

85. Id. at 16. Though not explained, the point is that earning just less than the monopoly priceunder the umbrella - is superior to earning some fractional share of the monopolist's-Standard Oil'sprofits. This is another familiar Chicago School argument. See George J. Stigler, The Dominant Firm and the Inverted Umbrella, 8 J.L. \& ECON. 167, 171 (1965).

86. Granitz \& Klein, supra note 24 , at 16.

87. Id. at 15 . For other examples of independent refinery sales at distress prices. See e.g., id. at is n. 38,38 n. 100 . 
acquisitions in Cleveland ${ }^{88}$ Granitz and Klein acknowledge that the revelation of the South Improvement Company agreement led to great protests by crude oil producers, the public, and politicians, and that ultimately the agreement never went into effect. Nevertheless, Standard Oil successfully acquired all of the independent refiners in Cleveland in the three months between the formation of the agreement in December 1871 and its abandonment in March $1872 .{ }^{89}$ As Granitz and Klein put it,

[T] he timing evidence, namely, that all the Cleveland acquisitions occurred in essentially a 3-month period after the South Improvement Company was established but before the Company was forced to disband, suggests that Rockefeller did use the threat of his prospective transportation cost advantage as a member of the South Improvement Company to induce his Cleveland rivals to sell out. ${ }^{90}$

Though the South Improvement Company agreement did not go into effect, Granitz and Klein argue that Standard Oil continued to police a railroad cartel on terms similar to the South Improvement Company agreement in the years after $1872,{ }^{91}$ though in subsequent agreements the shipment shares allocated to the respective railroads differed quite substantially. ${ }^{92}$ They do not attempt a careful explanation of why the respective shipment shares changed over time (nor do I, a subject worth further study), except with respect to the initial entry of the Baltimore \& Ohio Railroad. ${ }^{93}$ This railroad created a route for oil shipment from Pittsburgh to the south and east to Baltimore, forcing the cartel to allocate a transport share to the Baltimore \& Ohio.

Granitz and Klein's discussion of Standard Oil's consolidation of refinery control in the years after it had acquired control in Cleveland in 1872 is somewhat less detailed. Standard Oil acquired an evener in New York in $1872 ; ;^{94}$ two years later, in 1874 , it acquired the eveners in Pittsburgh and Philadelphia. ${ }^{95}$ From 1876 to 1879, Standard Oil acquired the remaining independents in all of the refining cities, consolidating its national refinery monopoly by $1879 .{ }^{96}$ Granitz and Klein again attribute these acquisitions to Standard Oil's control of shipping prices by agreement

88. Id. at $14-15$.

89. Id.

90. Id. at $\mathbf{1 5}$.

91. Id. at 21-23. See also Klein, supra note 16, at 490 .

92. See Granitz \& Klein, supra note 24 , at 34 tbl.4.

93. Id. at 32

94. Id. at 9 n.27.

95. Id. at 18 .

96. Id. at 23 . 
with the railroads, mirroring the 1871 South Improvement Company agreement. $^{97}$

Granitz and Klein admit that Standard Oil's policing agreement with the railroads did not operate perfectly, though if the South Improvement Company drawback agreement remained in effect as they assert, it is not clear why. As mentioned, the oil freight allocations among the railroads were frequently revised. ${ }^{98}$ More seriously, in 1876 the agreement broke down completely. An affiliate of the Pennsylvania Railroad, the Empire Transport Company, encouraged by the Pennsylvania Railroad, entered refining on a significant scale, building refineries with the capacity of 4000 barrels per day, equaling one-third of the Pennsylvania Railroad's allocation under the cartel agreement. ${ }^{99}$ This led Standard Oil to an extraordinary form of retaliation: Standard Oil boycotted the Pennsylvania Railroad, shutting down its Pittsburgh refineries altogether and shifting all refining to Cleveland and New York, leading the railroads to engage in a brutal price war with the Pennsylvania. ${ }^{100}$ The episode is referred to as the "Empire Rate War." This is clearly predatory behavior under modern standards and it led the Empire Transport Company and the Pennsylvania Railroad ultimately to surrender in October 1877 and enter into a new agreement allocating oil freight percentages among the railroads. ${ }^{101}$ After its predatory victory, Standard Oil purchased all of the refining assetstank cars, refineries, and the pipeline network — of the Empire Transport Company. ${ }^{102}$

A further episode that Granitz and Klein claim confirms their theory is Standard Oil's behavior with respect to pipelines. During the late 1860s and early $1870 \mathrm{~s}$, there was substantial investment in oil pipelines as an alternative means of transporting crude oil. In the early years, these pipelines gathered oil from staging points near oil wells and sent the oil to local railroads to then ship to the refiners. Later, as pipeline technology improved, the pipelines connected from staging points directly to the refiners. ${ }^{103}$ In 1875 , the Columbia Conduit Company sought to connect a

97. Id. at 23 .

98. Id. at 34 tbl.4 (showing reallocations from the 1871 South Improvement Company agreement in $1874,1875,1877,1880$, and 1883 ).

99. Id. at $28 \mathrm{n} .66$.

100. Id. at 28 .

101. Id. at 29

102. Id. at 29 n.71.

103. For a discussion of these developments, see ARTHUR MENZIES JOHNSON, THE Development of American Petroleum Pipelines: A Study in PrIVAte ENTERPRise and Public POLICY, 1862-1906, at 70-99 (1956). 
pipeline from the Oil Regions all the way to Pittsburgh. ${ }^{104}$ The proposal was opposed by the Pennsylvania Railroad, which had its own railroad spurs carrying oil over this route. ${ }^{105}$ The Columbia Conduit Company prevailed and later delivered oil directly to the Baltimore \& Ohio Railroad, again strenuously opposed by the Pennsylvania Railroad. ${ }^{106}$ As pipeline technology developed, in 1879, a separate company, Tidewater Pipeline, developed a line carrying crude oil from the Oil Regions over the mountains to Williamsport, Pennsylvania, connecting to the Reading Railroad (not a member of the cartel) for delivery to New York. ${ }^{107}$ Standard Oil tried to block the Tidewater Pipeline by various legal tactics, but ultimately failed. ${ }^{108}$

Granitz and Klein interpret Standard Oil's effort to block the Tidewater Pipeline as additional evidence of its joint conspiracy with the New York Central, Erie, Pennsylvania and, by this time, the Baltimore \& Ohio railroads. ${ }^{109}$ The point is that, as a refiner, Standard Oil would benefit from the creation of a lower-cost means of transporting oil to the East, such as the Tidewater Pipeline. The Pennsylvania Railroad's opposition to the pipeline is understandable; the pipeline could only divert oil transport from the railroad, as it did. ${ }^{110}$ That Standard Oil joined in opposition to the pipeline is regarded as confirming evidence to Granitz and Klein that the Standard Oil refining monopoly relied on, and was made possible by, the joint agreement with the railroads. ${ }^{111}$

As mentioned, Granitz and Klein interpret the history of oil developments over these years as reflecting an agreement between the railroads (first, among the four eveners, and later, Standard Oil alone) to share profits from their monopolization of refining and the transport East of crude and refined oil. ${ }^{112}$ They invoke several more particular facts to support this interpretation. First, they examine published shipment rates less announced discounts, and calculate that Standard Oil paid higher real rates after the South Improvement Company agreement than presumably what it had paid before. ${ }^{113}$ Although not seriously discussed by Granitz and

104. Granitz \& Klein, supra note 24 , at $31-32$.

105. Id. at 32 .

106. See id. (discussing the rates that the "B\&O-conduit combination" offered).

107. Id. at 32.

108. Id. at $32-33$.

109. Id. at 33 .

110. Id.

111. Id.

112. See also Klein, supra note 16, at 468-73.

113. Granitz \& Klein, supra note 24 , at 10, 19. See also Klein, supra note 16, at 468-69. 
Klein, these data are questionable because it is very difficult to determine exactly what rates any railroad paid given the practice of secret rebates, questions over freight classification, alleged spurious weight measurements, free cartage, and the like. ${ }^{114}$

Second, Granitz and Klein show that, on a "weight per ton mile" basis, shipment rates for both crude and refined oil were greater than rates for grain and coal. ${ }^{115}$ This fact, too, is ambiguous. Natural monopolies engage in - that is, must engage in-many forms of price discrimination. In the case of railroads, rates were often set according to the value of the underlying product, irrespective of weight. ${ }^{116}$ More generally, from an economic perspective, natural monopolies aspire to set rates according to the competitive alternatives available to the shipper (Ramsey pricing) which will inevitably lead to rates not equalized by weight. Granitz and Klein's "weight per ton mile" measure, as between grain and oil, does not generally support their argument. The trunk railroads played a minor role in the transport of grain to the East Coast because of the apparent competitive advantage of shipment by water through the Erie Canal. According to the brilliant study of railroad cartels by Paul MacAvoy, discussed further below, ${ }^{117}$ in $1871,12.1$ of 12.9 million bushels of wheat (91 percent) were shipped from Chicago to the East Coast by water; of wheat, the three trunk railroads shipped 9 percent; of corn, 7 percent; of oats, 1 percent. ${ }^{118}$ Obviously, trunk railroad rates had to be responsive to competition by water; with respect to grain, they were not too successful in doing so. As indicated earlier, shipment of oil by water proved much less competitive. ${ }^{119}$

Third, in his contribution to this Symposium, Klein invokes judgments by Ron Chernow in Chernow's best-selling biography of Rockefeller, Titan. ${ }^{120}$ Chernow, based on his extensive review of Rockefeller's papers, concluded that Rockefeller did not exercise his market power over refining to exploit the railroads. According to Chernow, Rockefeller did not

114. Granitz \& Klein, supra note 24, at 7; WILLIAMSON \& DAUM, supra note 20, at 196.

115. Granitz \& Klein, supra note 24 , at 19-20, 21, 22, tbl. 3. See also Klein, supra note 16, at 475 .

116. See Granitz \& Klein, supra note 24 , at 22, tbl.3.

117. See infra note 273 and accompanying text.

118. Paul W. Macavoy, The Economic effects of Regulation: The Trunk-Line RAILROAD CARTELS AND THE INTERSTATE COMMERCE COMMISSION BEFORE 1900, at 6 (1965). Granitz and Klein only show an aggregate "grain" figure. Granitz \& Klein, supra note 24, at 22 tbl. 3.

119. See supra note 61 and accompanying text (showing that only 13 percent of oil was shipped east by water).

120. Klein, supra note 16, at 459. See also RON CHERnOw, TITAN: THE LIFE OF JOHN D. ROCKEFELLER, SR. (1998). Chernow's book was published two years after the Granitz and Klein article. 
"squeeze" the railroads on transport prices. ${ }^{121}$ Klein repeatedly invokes this conclusion. ${ }^{122}$ Klein also relies on Chernow's assertion that the railroads "probably derived more profit from [Rockefeller's] shipments than from those of rivals who paid higher rates" 123 to show the cooperative joint monopolization of Standard Oil and the railroads. ${ }^{124}$

Finally, Granitz and Klein build their analysis on their conclusion that the oil refining industry was not generally susceptible to monopoly. ${ }^{125}$ Entry into the refining industry was easy-a point repeatedly made. ${ }^{126}$ In contrast, entry into the oil transport industry-railroads-was difficult because of heavy fixed costs of investment. ${ }^{127}$ As a consequence-an analytical point made by $\mathrm{McGee}^{128}$ - the oil industry could more effectively be monopolized at the transport level than at the production or refining levels. ${ }^{129}$ This is an important point because it explains to Granitz and Klein why Standard Oil, as a refiner, needed to join with the railroads to effectively monopolize the industry. The railroads' efforts to cartelize had failed because of cheating; and refiners could not effectively cartelize because of ease of entry into the industry. This is the Granitz-Klein theory.

Standard and the railroads, by cooperating with one another, did something jointly that neither of them could do separately-they created a monopoly. In particular, they jointly established a transportation cartel, and the railroads facilitated Standard's growth so that Standard could effectively police the cartel with its dominant position in refining. ${ }^{130}$

As will be explained in the next section, ${ }^{131}$ there are several questions internal to the Granitz-Klein theory that raise doubts as to how explanatory the theory is. Most basically, the Granitz-Klein explanation of Standard Oil's oil refining monopoly provides, perhaps, the most significant support for the economic theory, originally proposed by Steven C. Salop and Thomas G. Krattenmaker, that firms can secure monopoly profits by

121. Id. at 113 .

122. See Klein, supra 16, at 106, 109, 110 n.48, 127.

123. CHERNOW, supra 120 , at 116.

124. Klein, supra note 16 , at $460,481,484$.

125. Granitz \& Klein, supra note 24 , at 1, 2, 23-24.

126. See id. at $1,2,23$.

127. Id. at 2, 41 (citing Lester G. Telser, A Theory of EfFicient COOPERATION AND COMPETITION 36-41 (1987)).

128. McGee, supra note 16 , at 142 ("Obstacles to entry are necessary conditions for [a monopolist's] success.").

129. Granitz \&Klein, supra note 24, at 23-24.

130. Id. at 24.

131. See infra Part III.C. 
raising rivals' costs. ${ }^{132}$ The Salop-Krattenmaker theory has received great attention although, to date, there have been very few real life illustrations in modern industrial experience. Granitz and Klein claim to have shown at least one instance-and an important instance- of the operation of the effect. Granitz and Klein also challenge the central Chicago School point that there is no economic purpose served by monopolization at more than one stage of the production process. ${ }^{133}$ Though there are some exceptions to the point, Granitz and Klein have not attempted to show that their theory of Standard Oil's success matches with one of those exceptions. Granitz and Klein do not emphasize either their support of the Salop-Kattenmaker theory or their difference from the Chicago School on these points, underestimating the novelty of their demonstration. Granitz and Klein claim to have shown at least one important instance contrary to the Chicago School proposition; if they are correct, theirs is a significant revision to the predominant school of thought. The next section suggests some problems internal to the Granitz-Klein explanation. Part IV will present a different explanation of developments in the oil industry.

\section{PRoblems INTERNAL TO THE GRANITZ-KLEIN THEORY}

As mentioned, the Granitz-Klein explanation of the creation and dominance of the Standard Oil monopoly is the most detailed and complete economic treatment in the literature. Nevertheless, there are several matters of fact and interpretation that do not seem completely explanatory.

\section{Ease of Entry to Oil Refining}

The assertion of low costs to enter the oil refining industry is important to the Granitz-Klein theory ${ }^{134}$ because it explains why Standard Oil felt the need to enter the agreement with the railroads to cartelize transport costs, rather than charge monopoly prices for refined oil as a typical monopolist. If entry to refining was easy-meaning achievable at low cost-monopolization of refining would be impossible. On this basis, Granitz and Klein repeatedly emphasize that Standard Oil, despite its

132. Salop \& Krattenmaker, supra note 32 , at 240.

133. See Richard A. Posner, The Chicago School of Antitrust Analysis, 127 U. PA. L. REv. 925, 927 (1979) ("[ []t makes no sense for a monopoly producer to take over distribution in order to earn monopoly profits at the distribution as well as the manufacturing level. The product and its distributions are complements, and an increase in the price of distribution will reduce the demand for the product.... [V]ertical integration must be motivated by a desire for efficiency rather than for monopoly.").

134. See Granitz \& Klein, supra note 24, at 1, 2, 23. 
nominal refining monopoly as measured in terms of market share, did not possess market power over oil refining. ${ }^{135}$ The industry structure in railroading was different, with high costs of entry such as obtaining rightsof-way, building the roadbed, and the like. ${ }^{136}$ As mentioned, Granitz and Klein conclude that a cartel among the railroads would be a superior means of extracting monopoly rents from the industry. ${ }^{137}$ This is the principal reason Standard Oil found it advantageous to enter into a bilateral monopoly agreement with the railroads and to police the railroad cartel.

There are two problems with the interpretation that entry into oil refining was "easy." First, Granitz and Klein do not explain the economic basis for the continued refining of crude oil in New York and other East Coast cities, such as Philadelphia, Boston, and Baltimore. If entry into crude oil refining were "easy," what was the point of maintaining refineries on the East Coast? Transporting crude oil to the East for refining was surely more costly than transporting lower volumes of oil already refined in the West.

Although not discussed by Granitz and Klein, many of the East Coast refineries had previously been coal oil refineries, refitted after petroleum oil prevailed over the distillation of coal oil. ${ }^{138}$ Granitz and Klein report that the conversion rate from crude to refined oil was 65 percent, implying a wastage of 35 percent. ${ }^{139}$ But they do not include in their figures the other byproducts from the distillation of crude oil: naptha (gasoline), lubricating oils, and other products. Although these data are not completely clear, if all of these byproducts were recovered, it appears that the wastage in volume in the conversion of crude was somewhere between 12 and 22 percent. ${ }^{140}$ It is also not evident whether there were differences between East Coast refineries and Pittsburgh/Cleveland refineries with respect to the production of these byproducts. Nevertheless, even though the transportation of crude rather than refined oil increased freight costs between 12 and 22 percent; the industry found it more profitable to reconvert the East Coast coal oil refineries rather than to open new refineries in the West that were closer to crude oil sources; suggesting that entry into oil refining was not as easy as represented.

Second, Granitz and Klein do not discuss the issue of the scale of oil

135. Id. at 1,26 .

136. See id. at 8 .

137. Id. at 18, 33. See also McGee, supra note 16 at 142.

138. WiLliamson \& DAUM, supra note 20 , at 110.

139. Granitz \& Klein, supra note 24 , at 20 n. 53 .

140. Derived from WILLIAMSON \& DAUM, supra note 20, at 739 app. B. 
refining operations. There is substantial evidence that refinery scale increased over time. ${ }^{141}$ It is not clear whether the minimum efficient refinery scale increased because of production efficiencies or because, equally probable, with larger oil volumes under control, more advantageous deals could be made with the railroads for shipment east. It may have been easy-requiring only a moderate investment--to build some form of an oil refinery, but much more difficult and costly to command sufficient output to extract from the railroads shipment discounts competitive to the discounts obtained by Standard Oil.

\section{The Role of the South Improvement Company}

The South Improvement Company agreement of 1871 is central to the Granitz-Klein theory and is the principal ground for the "raising rivals' costs" explanation. ${ }^{142}$ As discussed, according to Granitz and Klein, the agreement provided that Standard Oil in Cleveland, and the major refiners in the other refining centers, were to allocate aggregate oil shipments among the three competing railroad systems according to fixed percentages, and to receive rebates on their own shipments and drawbacks on the shipments of competing refiners and producers, suggesting a sharing of monopoly returns between the railroads and the evener refiners. ${ }^{143}$ The explanation initially appears plausible because the shipment allocation terms of the agreement resemble how a cartel of railroads might have fixed shipment shares to maximize profits, the maximization deriving from the higher rates charged to the independent refiners and producers. The payouts to the eveners in rebates and drawbacks can be interpreted as compensation for enforcing the fixed allocation among the railroads.

There are many reasons, however, to question the significance of the South Improvement Company to the development of the Standard Oil refining monopoly. Examined carefully, the economics of the arrangement and the subsequent history do not exactly make sense. First, according to Granitz and Klein, the combination of rebates and drawbacks gave such a substantial competitive advantage to Standard Oil as the evener in Cleveland that it enabled Standard Oil to buy up all of the competing Cleveland refineries, forming a refining monopoly in Cleveland. ${ }^{144}$ But given this competitive advantage to the eveners, why was Standard Oil the

141. Id. at 253 (discussing how new and advanced technology in refining stills helped increase the scale of refining); $i d$. at 615-16.

142. Granitz \& Klein, supra note 24 , at 23-27.

143. See supra notes $81-84$ and accompanying text.

144. Granitz \& Klein, supra note 24 , at $15,40$. 
only evener to buy up its rivals, not the eveners in the other refining cities: Pittsburgh, New York, and Philadelphia? Apparently, there were some acquisitions of independents by eveners in Pittsburgh. ${ }^{145}$ Granitz and Klein do not explain why Standard Oil in Cleveland took advantage of the South Improvement Company agreement to acquire its competitors, while other eveners failed to acquire their competitors; few acquired any.

Second, the rebates and drawbacks surely gave Standard Oil a competitive advantage over competing Cleveland refineries. But why would Standard Oil want to exploit that advantage by buying up the independent refineries, rather than simply receiving the accumulated drawbacks? Granitz and Klein argue that the purchase price that Standard Oil paid to acquire the independents was market value less the present value of expected drawbacks ${ }^{146}$ which, if true (it is a mere hypothesis), would make the transaction economically rational for Standard Oil. But how does Standard Oil calculate the present value of expected drawbacks given the extraordinary railroad price advantage that it would possess? In addition, why was it rational for the railroads to facilitate such transactions? With the Cleveland independents acquired by Standard Oil, there were no refineries in Cleveland to charge the higher cartel shipment rates.

Third, what features of the South Improvement Company agreement encouraged Standard Oil to buy up other eveners; the New York evener in 1872 then the Pittsburgh and Philadelphia eveners in 1874? The South Improvement Company agreement appears to have treated the eveners equally, at least in terms of rebates: each evener was given a substantial competitive advantage over the independents. ${ }^{147}$ But the agreement gave no evener any form of competitive advantage over the other eveners. Granitz and Klein do not discuss this point.

Fourth, but closely related to the earlier points, how did the South Improvement Company agreement, or the policies that succeeded it, lead to Standard Oil buying up all remaining refineries in all of the refining cities? Again, with these acquisitions, Standard Oil lost all of its drawbacks industry wide (possibly reflected in the purchase price for the individual refineries). The railroads, however, lost all of the clients from whom according to Granitz and Klein, they expected to extract a cartel profit, since they were committed by contract to guaranteeing Standard Oil the

145. Id. at 16 n.39.

146. Id.

147. Id. at 9-14. 
prescribed rebates.

Finally, and more basically, why would the railroads want to facilitate not only a monopoly over refining - where the monopoly would reduce output and therefore reduce oil shipments on the railroads - but also facilitate the creation of a monopsony over the purchase of oil shipment services? This is the basic Chicago School point about the benefits of monopolization at only one stage of the production process. ${ }^{148}$ Of course, the converse question is why would Standard Oil, in creating its refining monopoly, want to aid in the policing of a cartel of the providers of shipment services, a significant proportion of total refined oil delivery costs?

If the inevitable result of the railroads' creation of the South Improvement Company was to lead to the acquisition by Standard Oil of all independents in Cleveland-and, according to Granitz and Klein, subsequently of refiners in all other cities - the agreement backfired badly on the railroads. Granitz and Klein emphasize that the agreement was originated by the railroads. ${ }^{149}$ But according to their theory, the railroads' plan only served to subject them to the Standard Oil monopsony of oil transport.

It is problematic to base a theory of the Standard Oil refining monopoly on the existence of the South Improvement Company agreement because, as mentioned, the agreement never went into effect. ${ }^{150}$ Revelation of the agreement led to widespread protests by producers in the Oil Regions, by politicians, and by the public. The agreement was inadvertently made public in February 1872 and led to immediate adverse reaction by oil producers through the Petroleum Producers' Union, which organized an apparently effective boycott, refusing crude sales to the eveners. ${ }^{151}$ Within a month, on March 25,1872 , the railroads withdrew from the agreement, cancelling their South Improvement Company contracts. ${ }^{152}$ On April 1, 1872, the railroads entered into an agreement with the Petroleum Producers' Union confirming restoration of the previous shipment rate system, though it is not clear that the rates ever changed. ${ }^{153}$ One day later, on April 2, 1872, the Pennsylvania Legislature revoked the

148. See supra note 133 and accompanying text.

149. Granitz \& Klein, supra note 24 , at 9 \& n. 26 .

150. Id. at 14 .

151. Id.

152. Id.

153. Id at 15. 
South Improvement Company's charter. ${ }^{154}$

As legal documents, the South Improvement Company charter and the separate individual agreements with the three railroads are not totally precise as to how the agreement would have operated. ${ }^{155}$ Granitz and Klein's interpretation, mirrored by Chernow, ${ }^{156}$ is a possible, but not a definitive reading. The agreements refer to drawbacks on the aggregate transport of oil, but do not show how drawback amounts are to be distributed. Granitz and Klein presume distribution by shipments within cities, ${ }^{157}$ but the agreements do not make this clear.

Possibly more significant is that the South Improvement Company had shareholders with defined shares, all of them executives of the various eveners. According to the contracts, the rebates were to be subtracted from the shipment rates of eveners and so went to the separate refiners. It is not clear how the drawbacks were to be distributed. From a legal standpoint, the drawbacks would be paid to the shareholders-as an example, John D. Rockefeller owned 180 of the 2000 company shares; other refiner executives owned different numbers of shares. ${ }^{158}$ Neither Granitz and Klein nor Chernow discuss the issue, but their analyses presume that these executives would pass along the drawback amounts to their respective refinery companies, thus giving the eveners a further competitive advantage. Possibly, there were separate agreements to this effect, but there is no evidence of them. If not, and the executives anticipated pocketing the drawbacks, then the prospective competitive advantage created by the South Improvement Company was much lower, and limited to the rebates alone.

A further difficulty is that the shares in the South Improvement Company subscribed to by its executives, were not equal by refining city, nor do they appear to correspond with output per city or transport per city, though, again, most of the city-specific data address capacity, not actual output, so this point is not clear and deserves further study. But there are

154. Id.

155. See Petroleum Producers' Union, A History of the Rise and Fall of the SOUTH IMPROVEMENT COMPANY 97-121 (1872) (reprinting the contracts of some railroad companies). See also TARBELL, supra note 13, at 281 app.5 (reprinting the company's contract with Pennsylvania Railroad). The other railroad contracts are nearly identical.

156. CHERNOW, supra note 120, at 134-51. Chernow does not cite Granitz and Klein and gets some facts wrong, such as that the agreement ignored the New York refiners. $I d$. at 141 (Bostwick, a New York refiner, subscribed to 180 shares.) But see infra Table 1 n.a.

157. Granitz \& Klein, supra note 24 , at 10.

158. The person appointed President of the company owned 100 shares. CHERNow, supra note 120, at 136. See also infra Table 1. 
curious differences that were not explained by Granitz and Klein, Chernow, or others, and are not explained in this Article either, except to note the question. Shareholdings in the South Improvement Company, organized by refining city, are listed in the table.

TABLE 1. Shareholders in South Improvement Company

\begin{tabular}{lcc}
\hline Executives by City & Total Shares & Percent \\
\hline $\begin{array}{l}\text { Philadelphia and Pittsburgh } \\
\text { (W.G. Warden \& O.F. }\end{array}$ & 950 shares & $47.5 \%$ \\
Waring): & & \\
$\begin{array}{l}\text { Pittsburgh alone (Frew, } \\
\text { W.P. Logan, John L. } \\
\text { Logan, Charles Lockhart, }\end{array}$ & 50 shares \\
$\begin{array}{l}\text { R.S. Waring): } \\
\text { New York (Jabez }\end{array}$ & $2.5 \%$ \\
$\begin{array}{l}\text { Bostwick): } \\
\text { Cleveland (William and }\end{array}$ & 180 shares \\
$\begin{array}{l}\text { John D. Rockefeller, Henry } \\
\text { M. Flagler, O.H. Payne): }\end{array}$ & 720 shares \\
$\begin{array}{l}\text { Administration (Peter H. } \\
\text { Watson, President): }\end{array}$ & 100 shares & \\
\hline
\end{tabular}

Sources: This table is a compilation of information provided in PETROLEUM PRODUCERS' UNION, supra note 155, at 31 (discussing the identity and number of shares per executive) and WILLIAMSON \& DAUM, supra note 20 , at 348 (same).

${ }^{a}$ There is a question as to whether Jabez Bostwick's shares should be attributed to New York or Cleveland; Standard Oil bought out his refinery in 1872.

Note the comparatively larger proportion of shares owned by the Cleveland refineries, suggestive of the future power of Standard Oil.

If the distribution of drawback amounts was by shareholdings, then the potential competitive effect of the agreement as among the refiners is much more difficult to interpret. The eveners still had the advantage of the rebates. But, if the executives who subscribed to shares in the South Improvement Company were planning to pocket the drawbacks personally, rather than to pass them on to their refiner companies, the theory that the agreement created such a competitive disadvantage to the independents as to lead them to sell out at distress prices to Standard Oil is more difficult to support.

Further, the oil industry literature interprets the South Improvement Company agreement as anticipating membership by all refiners that agree 
to comply with its provisions, not just the eveners. ${ }^{159}$ Article III of the agreements between the South Improvement Company and the individual railroads provides for identical rebates to any refiner that agrees to ship on equivalent terms. ${ }^{160}$ Whether this means admission to all refiners or admission to refiners who ship at Standard Oil and the other eveners' capacity is not known. Thomas Scott, of the Pennsylvania Railroad, who apparently devised the plan, told the producers that the South Improvement Company was "intended to include the entire trade." 161 This is consistent with giving shares to the organizers, not to the refining companies. If the South Improvement Company agreement, with its rebates and drawbacks, were open to all refiners and producers, then the Granitz and Klein interpretation of the agreement-that rebates and drawbacks went to the eveners while all others were subjected to higher rates-is not supportable. Again, given the failure of the agreement, it is not known how it would have operated.

Finally, the exposure of the South Improvement Company agreement, as mentioned, generated substantial public controversy-including rioting and burning of South Improvement Company members' properties. The exposure also led to extensive state and federal legislative investigations into the agreement. At one of these hearings, Peter H. Watson, who was the appointed President of the South Improvement Company, testified that the basic idea of the company was to bring in members (and presumed stockholders) from all the oil refining companies in the country. ${ }^{162}$ According to Watson's testimony (though he appears to have been under severe stress at the time), the basic idea of the South Improvement Company was to rationalize the entire industry by creating a cartel of refiners, settling terms among the railroads, and trying to reach some agreement with the oil producers (drillers). ${ }^{163}$

I believe this to be an important point and, as shall be explained in the next part, is consistent with an alternative explanation of the creation of the Standard Oil refining monopoly that describes it as a merger-to-monopoly firm; creating both monopoly and monopsony power, though challenged by competing firms to cartelize the oil industry at different stages of industry

159. WILLIAMSON \& DAUM, supra note 20, at 350. See, e.g., MAYBEE, supra note 30, at 325 , 343-44 (providing an example of the New York Petroleum negotiations with South Improvement Company).

160. PETROLEUM ProduCERS' Union, supra note 155, at 97-121.

161. MAYBEE, supra note 30 , at 363.

162. PETROLEUM PRODUCERS' UNION, supra note 155, at 92.

163. Id. 
production. Quite contrary of Granitz and Klein, I do not believe that there is support for either the "cartel ringmaster"-policing-the-railroad-cartel theory ${ }^{164}$ - or the point (shared by McGee) that cartelization was more effectively achieved at the railroad than at the refiner level of production. ${ }^{165}$ The explanation will also show why Standard Oil in Cleveland, rather than any refiner in any other city, succeeded in creating the monopoly. Rockefeller's "business acumen" surely had something to do with Standard Oil's success, but it was business acumen in forming a monopoly. Unique economic factors-admittedly, that Rockefeller and his associates exploited-were importantly instrumental in the success of the refining monopoly.

\section{COMPETING CARTELS AND THE ECONOMIC REASONS FOR THE SUCCESS OF THE STANDARD OIL REFINING MONOPOLY}

This part presents a theory of the creation and success of the Standard Oil refining monopoly different from the Granitz-Klein theory. During this period, there were combinations - that is, cartels-attempted at all stages of the production and sale of refined oil; combinations attempted among oil drilling producers, combinations attempted among the gathering pipelines that transported crude oil to the railroads and refiners, combinations attempted among crude oil refiners, and combinations attempted among the railroads that transported crude and refined oil east for ultimate export. Only Standard Oil, through the creation of a monopoly by merger with its acquisition of all competing refiners, succeeded in controlling the industry.

The producers-again, drillers--tried repeatedly to cartelize to reduce production of crude oil in order to raise crude oil prices. ${ }^{166}$ Some of these efforts had temporary success; over the long run, however, all of them failed, chiefly because of the large number of competing refiners given the prevailing property rights regime-called "the rule of capture"-that without centralized organization, created incentives for overproduction. ${ }^{167}$

The gathering pipelines failed in efforts to cartelize because they also were too numerous and operated independently with quite disparate interests. ${ }^{168}$ There was no connected network; some of the gathering pipelines were competitors; others were dedicated to specific wells in local

164. See supra note 32 and accompanying text.

165. See supra note $127-30$ and accompanying text.

166. See infra Part IV.A.

167. See infra note 181 and accompanying text.

168. See infra Part IV.B. 
areas. The benefits of cartelization are attenuated in these conditions. The railroads, however, in particular the Pennsylvania, saw the potential benefits of controlling the gathering pipelines and first tried to capture them. ${ }^{169}$ Following the 1872 South Improvement Company debacle--that resulted in an effective boycott-Standard Oil saw the danger from a monopoly of gathering pipelines, especially in the hands of the railroads. A gathering pipeline monopoly would create a dual monopoly problem. After 1872 , Standard Oil moved aggressively, and ultimately successfully, to acquire a monopoly over the gathering pipelines for itself, outmaneuvering the Pennsylvania Railroad. ${ }^{170}$

The railroads repeatedly entered into agreements to fix railroad rates. All had broken down because the economics of natural monopoly industries support providing transportation services at any price above- or at the minimum equal to-marginal cost to sustain the business. ${ }^{171}$ This well-known economic fact did not deter the railroads from trying to cartelize, but it did prevent them from successfully achieving that end.

Standard Oil, as a refiner, successfully monopolized the industry over the weaknesses of the competing cartels for two economic reasons. First, Standard Oil did not face the producers' economic problem of incentives to overproduction given absence of central control. Indeed, Standard Oil's consolidation of the industry allowed it to substantially reduce oil refining overcapacity, which it did, adjusting refining production at many points over the succeeding years. ${ }^{172}$ Second, Standard Oil did not face the railroads' economic problem of needing to add capacity at reduced prices in order to attempt to achieve revenues equal to average costs. As shall be explained, Standard Oil in Cleveland-disadvantaged geographically, but advantaged competitively - proved best able to exploit the railroads' costrevenue difficulties. ${ }^{173}$ Indeed, it is my view that Standard Oil sought a monopoly over refining chiefly in order to create monopsony buying power against the crude oil producers and the railroads.

Quite contrary to the Granitz and Klein "cartel ringmaster" explanation centering on the maintenance of the railroad cartel, this part explains that Standard Oil, a refiner, succeeded not by joint agreement with the railroads-the South Improvement Company idea was discarded just as

169. See infra note 240 and accompanying text

170. See infra notes $246-48$ and accompanying text.

171. See supra notes $72-73$ and accompanying text.

172. See infra Part IV.D.1.

173. See infra Part IV.D.3. 
Standard Oil gained control-but over and against the railroads. There is also evidence, though it is tentative, that Standard Oil monopolized the sale of refined oil for export though, apparently, at a lower level. ${ }^{174}$

According to economic theory, for an industry characterized by monopoly at some level, there is only one profit-maximizing price of the finished product. At which level of production the monopoly is exercised to ultimately generate the appropriate monopoly price is a matter of comparative elasticities of input supply and consumer demand. Here, as mentioned, there is evidence of Standard Oil's exercise of monopsony power against both the producers and the railroads, and of some monopoly power in the export of refined oil.

Chernow quotes Rockefeller as stating, "The day of combination is here to stay. Individualism ${ }^{175}$ has gone, never to return."176 Joseph Potts, head of the Empire Transport Company, Standard Oil's enemy in the Empire Rate War, ${ }^{177}$ testified before a Congressional investigation in 1888 that the dynamics of competing efforts to monopolize the industry were well understood at the time,

We reached the conclusion that there were three great divisions in the petroleum business-the production, the carriage of it, and the preparation of it for market [refining]. If any one party controlled absolutely any one of those three divisions, they practically would have a very fair show of controlling the others. ${ }^{178}$

As we shall see, Potts and others may have acknowledged the battle over monopoly of the oil industry, but they all lost out to Standard Oil. There are good economic reasons that explain why Standard Oil, a refiner in Cleveland, amassing substantial capacity to control the railroads, gained absolute control over the oil trade. Section A describes efforts to form cartels among the producers; Section $\mathrm{B}$, among the gathering pipelines; Section C, among the trunk railroads. Section D will explain Standard Oil's creation of the refining monopoly that, once successful, gave it monopsony power over the production of crude oil as well as over the purchase of railroad transport services. Though the price data are difficult to interpret, Section D will also show evidence suggestive of Standard Oil charging monopoly prices for refined oil for export.

174. See infra notes 354-55.

175. Presumably, Rockefeller means individual firm competition.

176. CHERNOW, supra note 120 , at 148 .

177. See infra notes $337-42$ (describing the telling episode of the Empire Rate War among the competing cartels).

178. JOHNSON, supra note 103 , at 58. 


\section{A. Combinations Among the Producers}

Serious drilling for oil began in the Pennsylvania Oil Regions in 1859, and developed rapidly thereafter. By 1862, 495 wells had been drilled or were in the process of drilling; by $1869,1186 .{ }^{179}$ Crude oil production increased from 8500 barrels in 1859 , to over three million barrels in 1862 , to over 4.2 million barrels in $1869 .{ }^{180}$ These numbers alone suggest that the oil production industry was very competitive. Competition among the producers was enhanced by the prevailing property rights rule regarding oil collection-"the rule of capture." "The rule of capture" provided that, though an oil field may extend beneath many differently owned properties on which there were competing oil wells, those wells first pumping the oil could keep all that they had pumped, ${ }^{181}$ creating an incentive to pump as fast as possible. This incentive, given the absence of coordination, led to the rapid expansion of supply and to the decline in price of crude oil.

According to Derrick's, as early as November 1866, there was 'talk among the producers along the creek of forming a combine for the purpose of attempting to make better terms with the refiners, in the matter of the price of the crude product." ${ }^{182}$ Later that month, Derrick's reports a "movement" to create an Oil Buyers' Association, "to erect storage tanks along the creek ... to regulate ... the prices of the crude product." 183 This refers to a proposal to create a joint-selling agency-a cartel that the producers would attempt again at later periods.

An organization called the Petroleum Producers' Association ("Producers' Association") was created somewhat later. ${ }^{184}$ Apparently, in its early years, the Producer's Association addressed issues relating to

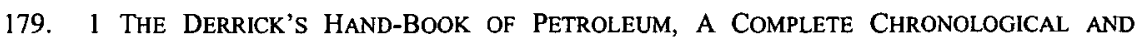
STATISTICAL REVIEW OF PETROLEUM DEVELOPMENTS FROM 1859 TO 1898, at 788 (2006 ed.) (1898) [hereinafter DERRICK's]. Derrick's is an extraordinary resource that has compiled early oil news and statistics. It reports daily local Oil Region newspaper accounts of events from the early $1860 \mathrm{~s}$ on; chiefly from Oil Region newspapers including The Derrick of Oil City. Pennsylvania, plus aggregate statistics. Citations to the source can be confusing. The first edition of Derrick's (1898) was printed in two volumes, the first volume covering developments from 1859-1897; the second from 1898-1899. Derrick's was reprinted in 2006, but dividing volume one into two volumes, though the pages remain continuous. I have had access only to the 2006 edition of Volume 1, but will ignore the 2006 volumesplitting which will make the references here consistent with those of earlier books, such as Williamson \& Daum. All citations in this Article are to Volume 1 of Derrick's.

180. Id. at $804-05$.

181. WILLIAMSON \& DAUM, supra note 20, at 161.

182. DERRICK's, supra note 179 , at $80-81$.

183. Id. at 81 .

184. Derrick's reports the annual meeting of the Association in January 1868. Id. at 98. WILLIAMSON \& DAUM, supra note 20, at 351. 
standardizing oil measurement and a joint effort with the Philadelphia Petroleum Association to oppose federal oil taxes. ${ }^{185}$ At least beginning in 1869, however, the Producer's Association became an agent for cartelization. Derrick's reports that in February 1869, “[o]utside markets are unfavorable and the market along the creek is weaker. Producers meet at Oil City and discuss means of organization for the betterment of the trade." 186 In August and September 1869, the Producers' Association began to collect aggregate production statistics, dividing the regions into fifty districts with individual reporting obligations. ${ }^{187}$ As will be seen, this organization later supported joint sales agency efforts.

Shortly thereafter, in June 1869, the producers met in Oil City and agreed to stop new drilling for three months ${ }^{188}$ in order to reduce supply and force up the price of crude. The agreement failed. Derrick's reports, shortly thereafter, "more wildcatting in progress than at any time since the discovery of oil." 189

Other attempts were made to limit production and sales. In December 1870, a "[c]orner in oil, engineered by Titusville parties, sends the crude market up 40c a bbl. [barrel]." 190 But this, too, was fleeting. Throughout 1871 , aggregate production continued to increase. ${ }^{191}$

In February 1872, the South Improvement Company agreement was disclosed. The producers responded vehemently. According to the Petroleum Centre Record, the producers viewed the agreement as a "gigantic combination among certain refiners and [the railroads] ... of robbery and swindling." 192 Although not made clear in Granitz and Klein, the producers were themselves shippers of crude oil to the refining cities, both east and west. Thus, according to the South Improvement Company agreement, not only were the independents put at a competitive disadvantage to the eveners, but the producers too, because the eveners would have received drawbacks on the shipments of both producers and competing refiners. This explains the virulent reaction of the producers to the South Improvement Company plan. ${ }^{193}$ The producers met in a famous

185. DERRICK'S, supra note 179 , at $98-100$.

186. Id. at 111-12.

187. Id. at 116 .

188. Id. at 132 .

189. Id.

190. Id. at 139 .

191. Id. at $142-58$.

192. Id. at 168 .

193. Neither Granitz and Klein, nor I, have been able to distinguish empirically the volume of shipments over time by producers versus refiners. The Granitz-Klein theory assumes that the South 
gathering at the Titusville Opera House ${ }^{194}$ condemning both the eveners and the railroads. ${ }^{195}$ The producers agreed to boycott the eveners, including Standard Oil, cutting off sales of crude to them. According to Derrick's, they also agreed to blacklist the three trunk railroads, ${ }^{196}$ though what this means is uncertain: how else were they to transport the oil east?

Again, to force crude prices up, the producers agreed to halt drilling new wells and to stop operations on existing wells on Sundays. ${ }^{197}$ They formed a new organization, the Oil Mens' League, to lobby the Pennsylvania Legislature to enact a "free pipe" bill, which would allow companies to construct new gathering pipelines without securing individual charters from the Legislature, which they regarded as corruptly influenced by the railroads and refiners. ${ }^{198}$ In April 1872, however, the Pennsylvania Legislature repealed the charter to the South Improvement Company and the suspension on new drilling apparently ended. ${ }^{199}$

As indicated earlier, during this period, Standard Oil consolidated its refinery ownership in Cleveland and purchased refineries in New York and Pittsburgh. By September 1872, the producers complained about the combination of refiners and its effect on crude prices and accumulating inventories. ${ }^{200}$ The producers agreed again to shut down production for thirty days. ${ }^{201}$ Derrick's reports in October "that nearly every oil well in the region is shut down" and that "production has been cut from 16,000 to 18,000 bbls. per day down to between 5,000 and 6,000 bbls."202 Later in October, the Producers' Council met in Oil City to reaffirm the thirty-day shutdown. ${ }^{203}$ Ten days later, yet another organization was formed, the Oil Well Workingmen's Association, that adopted a constitution and presented the producers with a plan for a "Petroleum Producers' Agency" which would serve as a single buyer and, subsequently, a sales agency for all

\footnotetext{
Improvement Company agreement chiefly affected refining shipments: thus, the great competitive advantage given to the evener refiners. That theory does not explain the extreme reaction of the producers who, if the agreement had gone into effect, would also have been victims with respect to drawbacks.

194. The fact that Titusville, Pennsylvania supported an opera house is indicative of the riches of the oil trade.

195. Williamson \& DaUM, supra note 20, at 350-51; CherNow, supra note 120, at 138-39.

196. DERRICK's, supra note 179, at 168.

197. Id. at 169.

198. See id. at 172 .

199. DERRICK's, supra note 179 , at 135.

200. Id. at $185,189$.

201. Id. at 189 .

202. Id. at 190,191 .

203. Id. at 191 .
} 
crude oil in the region, again to raise crude oil prices. ${ }^{204}$ By early November, the Petroleum Producers' Agency had raised over $\$ 1$ million for the effort. ${ }^{205}$ Standard Oil was reported to have instructed its buying agent in Oil City to agree to buy from the pool. ${ }^{206}$

The crude oil shutdown, however, ended on October 31. By December, Derrick's reports once again that the "market is demoralized." 207 By this time, as will be later discussed, ${ }^{208}$ the refiners, led by Standard Oil, had formed a National Refiners' Association. ${ }^{209}$ In midDecember, the National Refiners' Association and the Petroleum Producers' Agency reached a joint-sales-purchasing agreement, with the National Refiners' Association agreeing to buy solely from the Petroleum Producers' Agency, on terms determined by a joint committee to set the price of both crude and refined oil. ${ }^{210}$ But Derrick's reports that many communicants had written in condemning the deal, one stating that "the proposed coalition with the refiners will only put off for a time the evils they are combating," recommending "a six months shut down as a means of getting better prices for oil." 211 In an editorial, Derrick's itself "says that the Producers' Council is a failure, and intimates that a crash is imminent ... producers have been working for an impossibility, trying to bolster up prices while production is increasing and the demand is not sufficient to take care of the daily output." 212 Two days later, the "[m]arket has declined largely; all mutual agreements for sustaining prices have failed so far." 213

The producers, however, tried again. On December 24, 1872, the Producers' Council recommended that no new wells be drilled for the sixmonth period, from December 25, 1872 to July 1, 1873, and that current wells be shut down twelve hours each day. ${ }^{214}$ But the agreement between the producers and the refiners broke down. On January 15, 1873, the Producers' Council declared that, because it had never gone into effect, the

204. Id. at 193; WILLIAMSON \& DAUM, supra note 20, at 357.

205. DERRICK'S, supra note 179, at 194.

206. See id. at 195 .

207. Id. at 197.

208. See infra Part IV.D.1.

209. WILLIAMSON \& DAUM, supra note 20, at 356; CHERNOW, supra note 120 at 157.

210. DERRICK's, supra note 179,at 197-198.

211. Id. at 198 .

212. Id. at 199 .

213. Id. See also WiLliamson \& DAUM, supra note 20, at 359 (discussing the downward price trend following the agreement).

214. DERRICK's, supra note 179, at 199. 
agreement with the National Refiners' Association was annulled. ${ }^{215}$ Derrick's comments,

it turned out that the pledge to drill no wells for six months had tended to increase development by persons who wished to take advantage of the idleness of others. So we come to the end of this short-lived combination. It was wrong in principle, impossible in practice, and inconsistent with the record of the oil producers of Pennsylvania. ${ }^{216}$

Later in 1873, Standard Oil, having continued its acquisition of, or merger with, previously competing refiners, tightened the screws on the producers. As will be shown below, ${ }^{217}$ oil inventories in the region continued to rise. In June, Standard Oil disbanded the National Refiners' Association. ${ }^{218}$ One pipeline company began to charge for oil held in lines and refused to receive oil for storage. ${ }^{219}$ In July 1873, Derrick's reports the "[m]arket quiet and dull. Sellers appear willing to trade at present prices, but buyers are generally holding off, having confidence in a still further decline."220 As Standard Oil continued its acquisition to monopolize refining, Derrick's reports in October 1873, "[l]arge quantities of oil are running to waste ... for want of tankage"; 221 "[t] he low price of oil causes the shutting down of nearly all the wells in the Tidioute district."222 On November 17, Derrick's reports that "[t]he matter of shutting down both production and the drilling of wells as a means of bettering prices is again agitated in the oil regions." 223

The market continued similarly in 1874. In February, more pipeline companies announced that they would begin charging storage rates for oil not immediately shipped. ${ }^{224}$ In March, Derrick's advocates "a cessation of drilling in order to keep the market upon its upward course" 225 and, in April, reports a meeting in the lower fields to discuss, "the advocacy of another shut-down and suspension of drilling as a means of enhancing the

215. Id. at 201; WILLIAMSON \& DAUM, supra note 20, at 359.

216. DERRICK's, supra note 179 , at 201.

217. See infra notes 224-28 and accompanying text.

218. DERRICK's, supra note 179, at 208 (because Standard Oil "found itself hampered by the articles of association"); CHERNOw, supra note 120, at 160 (quoting Rockefeller as stating that "the producers' and refiners' associations were ropes of sand"); WILLIAMSON \& DAUM, supra note 20, at 360 (arguing that the Association disbanded because it was unable to control its members).

219. DERRICK'S, supra note 179 , at 207.

220. Id. at 209.

221. Id. at 215.

222. Id. at 217.

223. Id.

224. Id. at 223.

225. Id. at 225. 
price of crude ... [and] to take action in the matter of a 90-day cessation of drilling operations." 226 But by May, "the shut-down movement was not as successful as it should be."227 And by June, Derrick's states,

Leading operators in the Butler county field meet at Petrolia to discuss the situation and to devise, if possible, means to remedy existing depression in the trade. Shut downs were talked of and thrown aside as impracticable, and a committee was appointed to devise a plan for organizing all producing interests under one head . . . 228

Nothing would come of the effort, as the Standard Oil refining monopoly continued to advance.

As is evident from this history, the producers attempted repeatedly to combine in order to raise the price of crude oil. In these efforts, the principal tactic was to agree to suspend new drilling. There is an important economic point here: once a well was drilled, absent coordinated action, the incentives created by the "rule of capture" were too strong to allow curtailed production. The source of the problem was not the "rule of capture" itself; the problem was the inability to coordinate. ${ }^{229}$ Given the inability to control extraction, the only potential means of reducing output was to stop drilling new wells. But even agreements to stop new drilling failed, and the producers - as shall be explained further below ${ }^{230}$ - became subject to the monopsony of the refiners, led by Standard Oil.

\section{B. Combinations Among the GATHERING PIPELINES}

During the period of consolidation of the Standard Oil refining monopoly, the only existing pipelines were those that gathered oil from individual wells or from staging points near the wells. These pipelines delivered the oil to railroads or other means of transportation, and ultimately to the trunk railroads or the refiners. Trunk pipelines to the East Coast were not developed until much later, in 1879, and at first, transported only crude oil, not refined. ${ }^{231}$ When crude oil was first systematically drilled in the early 1860 s, it was shipped from the wells by wagon. ${ }^{232}$ Arthur Menzies Johnson, a pipeline historian, reports that in the early

\footnotetext{
226. Id. at 227.

227. Id. at 228 .

228. Id. at 233.

229. I am grateful to Robert Ellickson and Claire Priest for clarifying this point.

230. See infra Part IV.D.

231. JOHNSON, supra note 103, at 93-95.

232. Id. at 4 .
} 
years, there were 6000 two-team horse wagons transporting oil..$^{233}$ Later, oil was shipped by boat down the creeks in the Oil Regions to the Allegheny River for ultimate transport to Pittsburgh for refining or for direct shipment east. ${ }^{234}$ The creeks in the Oil Region were not large; shippers would build dams across them, accumulate water, and then release it-creating what is called a "freshet"-to carry the oil-laden boats downstream to the Allegheny. ${ }^{235}$ According to Johnson, a single freshet could accommodate 10,000 to 20,000 barrels of oil. ${ }^{236}$

Gathering pipelines were proposed in 1860 and the first successful pipeline was built in $1862 .{ }^{237}$ Initially, teamsters attacked the pipelines, breaking them up as late as 1863-1864. This led to the pipelines being buried, though with the decline of wagon carriage, the violence diminished. ${ }^{238}$ The individual pipelines faced competition from local railroads from an early point, but railroads, of course, could not connect to every well. ${ }^{239}$ Williamson and Daum report that the Pennsylvania Railroad moved to acquire pipelines to direct the crude oil to Pittsburgh for ultimate shipment east on the Pennsylvania before or after refining. ${ }^{240}$

As discussed earlier, the 1871 South Improvement Company agreement led to substantial agitation in the industry. ${ }^{241}$ The producers saw the railroads and refiners as creating a combination to harm them; they lobbied for a "free pipe" bill which would allow companies to build pipelines without obtaining independent charters and would give these companies rights of eminent domain to obtain pipeline routes. ${ }^{242} \mathrm{~A}$ bill to that effect was enacted by the Pennsylvania Legislature on March 12, $1872 .{ }^{243}$ As indicated, the producers also staged a boycott of the sale of crude to the eveners, including Standard Oil; they convinced the pipeline owners to also boycott the eveners. ${ }^{244}$ The producer-pipeline boycott appears to have been highly successful. Chernow reports that Standard Oil was forced to lay off 90 percent of its employees during the boycott. ${ }^{245}$

233. Id.

234. Id. at 2-3.

235. WILLIAMSON \& DAUM, supra note 20 , at 165.

236. JOHNSON, supra note 103 , at 3-4.

237. Id. at 5 .

238. Id. at 5-6. See also WILLIAMSON \& DAUM, supra note 20, at 184, 187.

239. JOHNSON, supra note 103, at 12-13. See also MAYBEE, supra note 30, at 380.

240. WILliAMSON \& DAUM, supra note 20, at 173.

241. See supra Part III.B.

242. JOHNSON supra note 103, at 20-21.

243. Id. at 20.

244. Id.

245. CHERNOW, supra note 120 , at 141 . 
Both the railroads and Standard Oil saw the point and capitulated.

After this episode, Standard Oil sought increasing control over the gathering pipelines, as had the Pennsylvania Railroad in the past. The Pennsylvania's affiliate, the Empire Transport Company, acquired pipelines; ${ }^{246}$ as did Standard Oil, affiliating with the American Transfer Company, and later, with United Pipelines, both owners of a number of gathering pipelines. ${ }^{247}$ According to Johnson, "Rockefeller and his associates seized upon ownership of gathering pipelines as a source of strength in the competitive struggle in the petroleum industry as well as a means of assuring a supply of crude oil for their refineries."248

From 1873 to 1874 , however, there was a period of depression in the industry; and it is estimated that pipeline capacity was twice the level of demand. ${ }^{249}$ In 1874 , the pipelines attempted a pooling agreement with the gathering railroads, which allocated a 36.5 percent share to the Standard Oil affiliates. ${ }^{250}$ It is not evident that it was effective. In 1875 , the pipelines alone attempted another pool. ${ }^{251}$

Creating a cartel among the gathering pipelines is inherently problematic. Cartels are effective when formed by direct competitors. Of the gathering pipelines, many-perhaps most-were not competitors; they connected individual oil wells or groups of oil wells to railroads for further shipment. Many of the individual pipelines probably possessed some local monopoly power over the wells they served. What could have been added by a cartel may not have been clear. Nevertheless, because they were a central element of the movement of crude oil to the refiners or to the east, control of the pipelines by the railroads would have created a substantial obstacle to Standard Oil's ambition of monopolizing the industry.

Standard Oil was consolidating its refining monopoly during this period, and it appears that it saw the threat of ownership of the gathering pipelines by the railroads, in particular, by the Pennsylvania over which its bargaining power was less. ${ }^{252}$ In response, Standard Oil increased its investment in the ownership of pipelines to deal with the threat. ${ }^{253}$ Johnson

246. JOHNSON, supra note 103 , at 28.

247. Id. at 29. See also CHERNOW, supra note 120, at 171 .

248. JOHNSON, supra note 103, at 30-31.

249. Id. at 37. See also WILLIAMSON \& DAUM, supra note 20, at 399.

250. See JOHNSON, supra note 103, at 37-38; WILLIAMSON \& DAUM, supra note 20, at 397, $402-$ 03; Chernow, supra note 120, at 172.

251. JOHNSON, supra note 103 , at 45 .

252. Id. at 47 .

253. Id. 
estimates that, over the period between 1872 and 1875, Standard Oil acquired one-third of the total capacity of the gathering pipelines. ${ }^{254}$ Derrick's reports the reaction to one of these acquisitions on August 14, 1873: "Rumors of the sale of the Fairview Pipe Line to the Standard Oil Company have been in circulation for the past few days; also that a gigantic monopoly had been organized between the pipelines, Vanderbilt [Wm. Vanderbilt, President of the New York Central Railroad] and other railroad magnates." 255

Williamson and Daum describe the significance of Standard Oil's acquisition of the pipelines more directly: "control over the gathering lines gave Standard a better bargaining position vis-à-vis the Pennsylvania Railroad."256

Competitive conditions in the industry were disrupted slightly in 1875 with the extension of the Atlantic Pipeline connecting sources in Pittsburgh to Freeport, a terminal of the Baltimore \& Ohio Railroad. ${ }^{257}$ This new pipeline created a direct connection to the Baltimore \& Ohio to transport east. ${ }^{258}$ At the time the Baltimore \& Ohio was not controlled by Standard Oil, which undermined the effectiveness of Standard Oil's pipeline and refinery control. ${ }^{259}$ Standard Oil reacted aggressively to this development; it acquired refineries in West Virginia and Ohio, which were served by the Baltimore \& Ohio. ${ }^{260}$

In 1878, the Tidewater Pipeline Company obtained a charter from the Pennsylvania Legislature to build a pipeline directly from Pittsburgh over the mountains to Williamsport to connect with the Reading Railroad (not subservient to Standard Oil) and then to the East Coast. ${ }^{261}$ The Pennsylvania Railroad opposed the charter joined, apparently, by Standard Oil. ${ }^{262}$ As mentioned, Granitz and Klein interpret Standard Oil's opposition to this pipeline as evidence of its collusion with the railroads. ${ }^{263}$ Why else would a refiner oppose a low-cost shipping alternative to the East, ${ }^{264}$ a

\footnotetext{
254. Id.

255. DERRICK's, supra note 179 , at 211.

256. WILLIAMSON \& DAUM, supra note 20, at 414.

257. JOHNSON, supra note 103 , at 51 .

258. Id.

259. Id.

260. See id. at 51-52. See also WILLIAMSON \& DAUM, supra note 20, at 418-19.

261. WILLIAMSON \& DAUM, supra note 20, at 440-41.

262. CHERNOW, supra note 120 , at 208 (reporting "wholesale bribery" of the state legislature to prevent approval of the pipeline).

263. Granitz \& Klein, supra note 24 , at 33.

264. Id.
} 
perfectly good question.

There is another interpretation of Standard Oil's opposition, however. As shall be detailed below, Standard Oil had established, by this point, monopsony power over both crude oil production and railroad services transporting oil east. ${ }^{265}$ The Tidewater Pipeline threatened that monopsony by opening up a new avenue for producers to ship their crude oil east. Important here is the fact, not totally acknowledged by Granitz and Klein, that it was not only refiners in Cleveland and Pittsburgh that were shipping oil east, but also producers who contracted for their own crude oil shipments. Where a means of transport is proposed that threatens to bypass the control that Standard Oil possessed over the railroads and the producers, opposition to its development should not be unexpected. The Pennsylvania Railroad's and Standard Oil's opposition to the Tidewater Pipeline, however, failed. Indeed, once the Tidewater Pipeline was shown to be technologically successful, Standard Oil rapidly invested in trunk pipelines of its own, and reduced dramatically the costs of oil shipment east. $^{266}$

Over the succeeding years, Standard Oil continued its progressive acquisition of the gathering pipelines. Following the Empire Rate War, discussed below, ${ }^{267}$ Standard Oil acquired Empire's pipelines, as well as its other assets. ${ }^{268}$ It also acquired the Columbia Conduit Company. ${ }^{269}$ When a competing refinery opened in Buffalo connected by a pipeline to the Oil Regions, Standard, in a notorious example of predatory activity, built a competing pipeline along side it; underpriced shipments to force the competing pipeline out of business; acquired the competing pipeline and refinery; then tore up its own pipeline and resorted solely to shipment through the previously competing pipeline it had acquired. ${ }^{270}$

Williamson and Daum state that, before securing its refinery monopoly, Standard Oil "used its pipeline monopoly to help subsidize its refineries in their competition with independents." 271 An article in the November 23, 1878 issue of the New York Sun describes the capture of the gathering pipelines as "a most important" tactic in Standard Oil's

265. See infra Part IV.D.

266. WILLIAMSON \& DAUM, supra note 20 , at $447-48$.

267. See infra notes 337-341.

268. JOHNSON, supra note 103 , at $64-65$.

269. WILLIAMSON \& DAUM, supra note 20, at 426.

270. See id. at 453; Granitz \& Klein, supra note 24, at 36; CHERNOw, supra note 120, at 206.

271. WILLIAMSON \& DAUM, supra note 20, at 427. 
movement to monopoly. ${ }^{272}$

\section{COMBINATIONS AMONG THE TRUNK RAILROADS}

It was no secret that the railroads combined to fix rates collusively. To the contrary, because rate fixing was not illegal prior to the Sherman Act, the railroads often publicly announced their agreements to fix rates in newspapers such as the Railroad Gazette. ${ }^{273}$ It is not evident that the railroads published agreements with respect to oil transport.

According to Rolland Harper Maybee, a railroad historian, the three trunk railroads entered price-fixing pools with respect to oil transport repeatedly over the period: in $1858,1859,1860$, and later in $1866 .^{274}$ As suggested by the reiteration of these agreements over short periods, the price-fixing agreements commonly broke down, with one or another railroad cheating on the agreed upon rate for oil delivery for the economic reasons discussed earlier. Williamson and Daum report that these agreements "were broken within weeks or months after they were signed,"275 consistent with MacAvoy's findings with respect to the railroads' agreements on grain transport. ${ }^{276}$ Maybee reports rate wars among the railroads after the agreements. ${ }^{277}$ These rate wars may not have been a result of the oil trade; Cornelius Vanderbilt, who owned the New York Central Railroad and Jay Gould, President of the Erie Railroad, were engaged in corporate battles at the time. ${ }^{278}$ Neither Granitz and Klein, nor I, know the comparative proportions on the trunk railroads of oil shipments versus other commodities, an empirical gap that impairs the analysis.

Granitz and Klein describe the 1871 South Improvement Company agreement allocating oil shipment shares among the three railroads as evidence of railroad collusion. As discussed, this interpretation of the agreement is not definitive. They also show subsequent agreed upon allocations of oil shipments among the railroads as indications of further railroad collusion: in 1875 (with the entry of the Baltimore \& Ohio

272. JOHNSON, supra note 103 , at 89 (citing an article by the New York Sun from November 23, 1878).

273. MaCAvoY, supra note 118 , at $25-26$. This is a terrific book examining trunk railroad cartel price fixing of rates for grain and coal based on the public data. Though the trunk railroads MacAvoy studied were the New York Central, Erie, Pennsylvania, and Baltimore \& Ohio, he did not examine charges for oil transport.

274. MAYBEE, supra note 30, at 89-90, 97, 134, 233.

275. WILLIAMSON \& DAUM, supra note 20, at 195.

276. MACAVOY, supra note 118 , at 25-26.

277. MAYBEE, supra note 30, at 191.

278. See Charles Francis AdAMS, JR. \& HENRY ADAMS, ChaPTERS OF ERIE 101-37 (1956). 
Railroad); 1877 (following the Empire Rate War); 1880 (after the success of the Tidewater Pipeline); and 1883-84 (again, after an agreement with the Tidewater). ${ }^{279}$

There is a different available interpretation of these agreements that depends upon identification of the source of economic power. One interpretation is that these allocations among the railroads result from the cartel of railroads coercing (somehow) the refiners to police the railroad cartel, the Granitz and Klein explanation. An alternative interpretation of these allocations among railroads is that Standard Oil defined them, as a monopsonist of railroad transport services, explained in the next section.

\section{COMbinations AmOng the Refiners AND THE CREATION OF the STANDARD OIL MONOPOLY}

This section describes the initial success of Standard Oil in progressing from a relatively small refiner on a national scale in Cleveland to its ultimate control over the oil industry. Subsection 1 will explain Standard Oil's attempts with other refiners to cartelize the refining industry-attempts that were unsuccessful-leading Standard Oil, in my view, to determine to create a refining monopoly on its own. Subsection 2 will show how Standard Oil exercised monopsony power over the producers of crude oil; Subsection 3, Standard Oil's monopsony power over the railroads; and Subsection 4, evidence of Standard Oil's monopoly pricing of refined oil.

\section{From Cartelization to Monopolization}

Standard Oil was incorporated in 1870 and was then the largest refiner in Cleveland, but of minor consequence nationally; ${ }^{280}$ the most important refiners were either in Pittsburgh or on the East Coast near the export terminals; there were also some refiners in the Oil Regions themselves. ${ }^{281}$ Cleveland refiners, including Standard Oil, however, possessed an advantage that the Pittsburgh and Oil Region refiners did not. As mentioned, transport costs of oil to the East Coast constituted a substantial proportion of total costs; Granitz and Klein estimate 38 percent, though there are lower estimates. ${ }^{282}$ From a geographic standpoint, Cleveland was

279. Granitz \& Klein, supra note 24 , at 34 tbl.4.

280. NEVINS, supra note 19, at 83.

281. See Granitz \& Klein, supra note 24, at 5-7.

282. Compare id. at 5, with WILLIAMSON \& DAUM, supra note 20, at 344 (estimating 20 percent). Williamson and Daum are not economists; the Granitz-Klein estimate is more plausible. There are 
at a disadvantage in this respect since it was located 150 miles west of the Oil Regions, requiring transport of crude oil an additional 150 miles west to Cleveland for refining, then transport of refined oil back an extra 150 miles on to the East Coast for export. ${ }^{283}$ Cleveland thus was an unlikely site for competitive refining in contrast to Pittsburgh, immediately downstream of the Oil Regions and with large quantities of coal nearby to fuel the refining process and compared to refineries built in the Oil Regions themselves as well as to East Coast refineries; though the East Coast refineries faced the increased costs of transporting the larger volume of crude versus refined oil. Nevertheless, after the consolidation of railroads to create the New York Central, which connected from New York to Albany to Buffalo and Cleveland, ${ }^{284}$ and the Erie Railroad, which connected from New York and New Jersey west, ${ }^{285}$ Cleveland, unlike Pittsburgh or the Oil Regions was served by two railroad systems, not one, plus the opportunity to ship by water during warm temperature months through the Erie Canal. ${ }^{286}$ This allowed refiners in Cleveland to play off the New York Central against the Erie Railroad and the Erie Canal to reduce rates for oil shipments, taking advantage of the declining average cost condition of the transport industry. 287

Rockefeller brought Henry Flagler into his firm in $1867 ;^{288}$ Flagler was apparently in charge of negotiating oil shipment rates among the railroads, ${ }^{289}$ though Rockefeller saw the point early on. ${ }^{290}$ Many commentators, including Granitz and Klein, Chernow, and others, have

difficulties with this calculation since one cannot be certain of the rates actually paid to the railroads.

283. See id. at 4.

284. Granitz \& Klein, supra note 24 , at 4. See also MAYBEE, supra note 30, at 127-28 (depicting the routes on a map).

285. Id.

286. See supra note 61 and accompanying text (noting that Granitz and Klein report lower railroad shipment rates during summer months).

287. Granitz \& Klein, supra note 24 , at 5 (noting that oil refining required chemicals that were costly to import to the Oil Regions). But this is actually the point. Because there were two railroad systems servicing Cleveland, transport of chemicals there was cheaper, than, say, to Pittsburgh, if the shipper were able to manipulate the competing railroads.

288. ChERNOW, supra note 120 , at 108 .

289. JOHNSON, supra note 103, at 15; CHERNOw, supra note 120 , at 111-12. Chernow describes Rockefeller and Flagler as playing off the three railroad systems against each other; this is not quite accurate. CHERNOW, supra note 120, at 111-12. Cleveland and Standard Oil were not connected directly to the Pennsylvania Railroad system, which had a terminus in Pittsburgh. It was only after Standard Oil had acquired a substantial share of Pittsburgh refineries and of the gathering pipelines that it was able to have direct influence over the Pennsylvania Railroad.

290. Chernow reports that, in 1863, when Rockefeller built his first refinery in Cleveland, he chose a location equally serviced by rail as by water down the Cuyahoga River to Lake Erie, intentionally to exploit competition in transport. CHERNOW, supra note 120, at 78 . 
noted the significance of Standard Oil's location in Cleveland. At the hub of two competing railroad systems as well as with access to a modestly competing system of water transport, Standard Oil was able to manipulate railroad rates. ${ }^{291}$ Klein presents a graphic example of how Standard Oil's promise of bulk shipping allowing it to negotiate lower railroad rates. ${ }^{292}$

As discussed, after the agreement on the South Improvement Company in late 1871, Standard Oil acquired most of the competing refineries in Cleveland. ${ }^{293}$ Granitz and Klein regard the South Improvement Company agreement as the effectuation of a railroad cartel allowing Standard Oil to "raise [its] rivals costs" chiefly on the basis of three facts: (1) the agreement was proposed by Scott of the Pennsylvania Railroad; (2) if implemented, it would raise the comparative transport costs of independents to the benefit of the railroads; and (3) it allowed Standard Oil to acquire the Cleveland refiners at "distress prices," presumably on account of the future transport cost differential. ${ }^{294}$

I have discussed earlier some of the internal difficulties with the Granitz-Klein interpretation of the South Improvement Company agreement. ${ }^{295}$ Here, I discuss the conditions of Standard Oil's acquisition of the other Cleveland refiners in 1872. Again, Granitz and Klein emphasize that Standard Oil was able to acquire the competing Cleveland refiners at "distress prices," which they attribute to the South Improvement Company agreement: prices were distressed because of the future transport cost differential as between the independents and Standard Oil. ${ }^{296}$

Theirs is an available interpretation, but it is not entirely convincing. It is well recognized that, in the early 1870 s, there was substantial refining overcapacity in Cleveland. ${ }^{297}$ Maybee reports that refining capacity was three times production. ${ }^{298}$ Chernow quotes Rockefeller as estimating that "90 percent of all refineries were operating in the red." 299 J.W. Fawcett, a rival refiner of Standard Oil in Cleveland, told Tarbell, "at that time some

291. Granitz \& Klein, supra note 24 , at 6 ; CHERNOW, supra note 120 , at 45 ; WILLIAMSON \& DAUM, supra note 20 , at $300-01$.

292. Klein, supra note 16, at 463. See also MAYBEE, supra note 30, at 266 (discussing the episode further); CHERNOW, supra note 120, at 113 (same).

293. See supra notes $89-90$ and accompanying text.

294. Granitz \& Klein, supra note 24, at 1, 9, 15-17.

295. See supra Part III.C.

296. Granitz \& Klein, supra note 24, at 16.

297. WILLIAMSON \& DAUM, supra note 20, at 307.

298. MAYBEE, supra note 30, at 318. See also id. at 276, 277 (discussing the increases in refining capacity); CHERNOW, supra note 120 , at 130 (reiterating the three-times refining capacity in 1870).

299. CHERNOW, supra note 120 , at 130. 
of the refineries were not making money, and they were the first to "run to cover' and sell out. Eventually all sold out." ${ }^{\text {300 }}$ According to Williamson and Daum, the number of refineries in Cleveland declined from 300 in 1863 to 100 between 1872 and $18733^{301}$

Interpreting these facts is complicated. First, this appears to be a period in which there were increasing scale economies in refining, which would imply that Standard Oil's consolidation achieved production efficiencies. Chernow quotes Rockefeller as stating, that the "foundational principle" of Standard Oil, the "theory of the originators ... [was] that the larger the volume the better the opportunities for the economies, and consequently the better the opportunities for giving the public a cheaper product without ... the dreadful competition of the late ' 60 's ruining the business." ${ }^{302}$ Alternatively, of course, output is less under monopoly than under competition. It is the reduced output that generates the monopoly profits. Thus, the consolidation and reduction in refining capacity is consistent with an objective of Standard Oil to cartelize the industry. Note that neither of these explanations involves raising rivals' costs, the GranitzKlein theory.

There is substantial additional evidence that Standard Oil's ambition was to cartelize the industry. Chernow quotes from Tarbell's papers showing that "some old Cleveland refiners" told her that Rockefeller convinced the independents to sell out to him with this argument,

You see, this scheme is bound to work. It means an absolute control by us of the oil business. There is no chance for anyone outside. But we are going to give everybody a chance to come in. You are to turn over your refinery to my appraisers, and I will give you Standard Oil Company stock or cash, as you prefer, for the value we put upon it. I advise you to take the stock. It will be for your good. ${ }^{303}$

By 1872 , Standard Oil had acquired a dominant position in Cleveland refining plus, as mentioned, refining interests in Pittsburgh and New York. ${ }^{304}$ But this position was far less than control over all crude oil refining. After the failure of the South Improvement Company agreement in March 1872, refiners in Pittsburgh, joined quickly by Rockefeller for

300. Id. at 145 .

301. WILLIAMSON \& DAUM, supra note 20, at 293.

302. CHERNOW, supra note 120 , at 150.

303. ChERNOW, supra note 120 , at 144 . Chernow describes this as a "menacing pitch," though it seems a totally rational invitation to merge to monopoly. See id.

304. See supra notes $94-95$ and accompanying text. 
Standard Oil, devised an alternative course. ${ }^{305}$ They formed the National Refiners' Association, that was open to any refiner that wished to join, ${ }^{306}$ to "handle the purchase of crude [oil] for all members, allocate refining quotas, fix prices, negotiate uniform freight rates with the railroads, and distribute profits according to the value of the property of each participant."307 In short, the National Refiner's Association was a buying and selling cartel of refiners. Rockefeller was the first President of the Association. 308

The monopsony features of the National Refiners' Association were not lost on the producers. They reacted by reinvigorating the Petroleum Producers' Association and the Petroleum Producers' Agency, discussed above. $^{309}$ As has been explained, these rival cartels were unable to coordinate. Rockefeller disbanded the National Refiners' Association in June $1873 .^{310}$

Rockefeller and Standard $\mathrm{Oil}^{311}$ engaged in one further effort to cartelize the refining industry. In the spring of 1875 , they created the Central Refiners' Association. ${ }^{312}$ The plan of this association was different in subtle respects from the National Refiners' Association that had failed two years earlier, and demonstrates Rockefeller's developing concept of consolidating the refining industry. As before, the Central Refiners' Association was to be open to all refiners that wished to join. ${ }^{313}$ But instead of what was basically a joint buying-and-selling agency, subscribers to the Central Refiners' Association were to lease their properties to the Association in return for stock. ${ }^{314}$ The executive committee of the Association would coordinate all purchases of crude oil and sales of refined oil and enter all transport agreements with the railroads and pipelines,

305. Williamson and Daum report that the plan, leading to the National Refiners' Association, was first proposed in April 1872, immediately after the failure in March of the South Improvement Company agreement. WILLIAMSON \& DAUM, supra note 20, at 356.

306. Note, this is consistent with the characterization that the South Improvement Company would be open to all other refiners. Of course, the National Refiners' Association did not include the railroads. See WILLIAMSON \& DAUM, supra note 20, at 357.

307. Id. at 356.

308. Id. at 357 .

309. See supra notes 44-46, 184-187 and accompanying text. See also WILliamson \& DAUM, supra note 20 , at 358 .

310. DERRICK's, supra note 179 , at 208. See supra note 218 and accompanying text.

311. In the many largely hagiographic histories, see, e.g., NEVINS, supra note 19; CHERNOW, supra note 120, all of Standard Oil's achievements are attributed to Rockefeller. It is difficult to know.

312. WILliamSON \& DAUM, supra note 20 , at 418 . Not discussed by Chernow or Granitz-Klein.

313. Id.

314. Id. 
dividing all profits. ${ }^{315}$ Rockefeller was to be President of the Central Refiner's Association. ${ }^{316}$

Note that, though the basic objectives of the respective associations were the same-a group agreement on crude oil purchase, refined oil sales, and negotiation over railroad shipping rates-the Central Refiners' Association would possess much greater control over individual firm activities than the National Refiners' Association. By the Central Refiners' Association agreement, individual refiner properties and their operations would be under direct control-by lease-rather than simply by contractual agreement (subject to secretive cheating and probably unenforceable under the common law as a restraint of trade). ${ }^{317}$ Through the Central Refiners' Association, Rockefeller and Standard Oil were seeking greater control over the refining industry, though still by the cartelization of independent refiners.

There is no evidence that the Central Refiners' Association was ever effective. ${ }^{318}$ According to my reading, Standard Oil, then skeptical of the success of cartelization, increased its course of buying up all of the refiners in the country, with some small exceptions. The large scale acquisitions in Pittsburgh, the Oil Regions, Baltimore, New York, and Philadelphia accelerated after $1875 .{ }^{319}$ By 1879 , Standard Oil controlled 90 percent of the refining industry. ${ }^{320}$

\section{Standard Oil's Monopsony Power over Producers}

It is difficult to measure the exercise of monopsony power. But there is evidence that suggests that Standard Oil exercised such power over the producers. First, the producers accused Standard Oil of under pricing its purchases of crude oil from 1873 on. ${ }^{321}$ They also accused Standard Oil of

315. Id.

316. Id.

317. It is an interesting legal question whether combination by leasehold was more likely to be enforceable than a direct agreement to combine. I would think it was, though I know of no legal precedent or discussion of this issue. Note also the close similarities from a legal standpoint of combination through the control of leasehold rights by an executive committee to combination through a trust controlled by a group of trustees or, as later with Standard Oil of New Jersey, through a holding company, controlled by a board of directors. See Standard Oil Co. v. U.S., 221 U.S. 1, 42 (1911).

318. See WILLIAMSON \& DAUM, supra note 20, at 418 (discussing the various roadblocks to the effective functionality of the Central Refiners' Association).

319. Id. at 420-21, 427-29.

320. Granitz \& Klein, supra note 24, at 2.

321. WILLIAMSON \& DAUM, supra note 20 , at $384,388$. 
using its control over pipelines to reduce crude oil prices. ${ }^{322}$ In 1877 , Standard Oil conditioned its purchase of crude oil only for immediate shipment, not for storage. ${ }^{323}$ The producers believed this policy artificially dampened crude oil prices. ${ }^{324}$ Somewhat later, in 1879, Standard Oil changed the market system again by requiring the submission of sealed offers to sell, an auction system, which the producers also believed had the effect of reducing prices. ${ }^{325}$

Monopsony over the production of crude oil is difficult, given the strong incentives for overproduction discussed earlier. ${ }^{326}$ Nevertheless, there is evidence that, following the consolidation of the Standard Oil refining monopoly, producers were forced to store increasing amounts of crude oil. The figure below, taken from Williamson and Daum, ${ }^{327}$ shows crude oil inventories over the years when Standard Oil was consolidating its refining monopoly. As is evident, inventories-crude oil produced, but not shipped for refining-increased dramatically after 1877 , exceeding crude oil output in 1881 . This is suggestive evidence of monopsony by Standard Oil over crude oil production.

322. Id. at 432; JOHNSON, supra note 103 , at 79 .

323. WILLIAMSON \& DAUM, supra note 20 , at 383-85.

324. Id. at 385 .

325. Id. at 387 .

326. See supra note 181 and accompanying text

327. WILLIAMSON \& DAUM, supra note 20, at 373 chart 15:1. Note that the graph of output and inventory appears to be on a logarithmic scale. 
FIGURE. Outputs, Inventories, and Prices of Crude Oil (per barrel), Appalachian Fields, 1874-1884

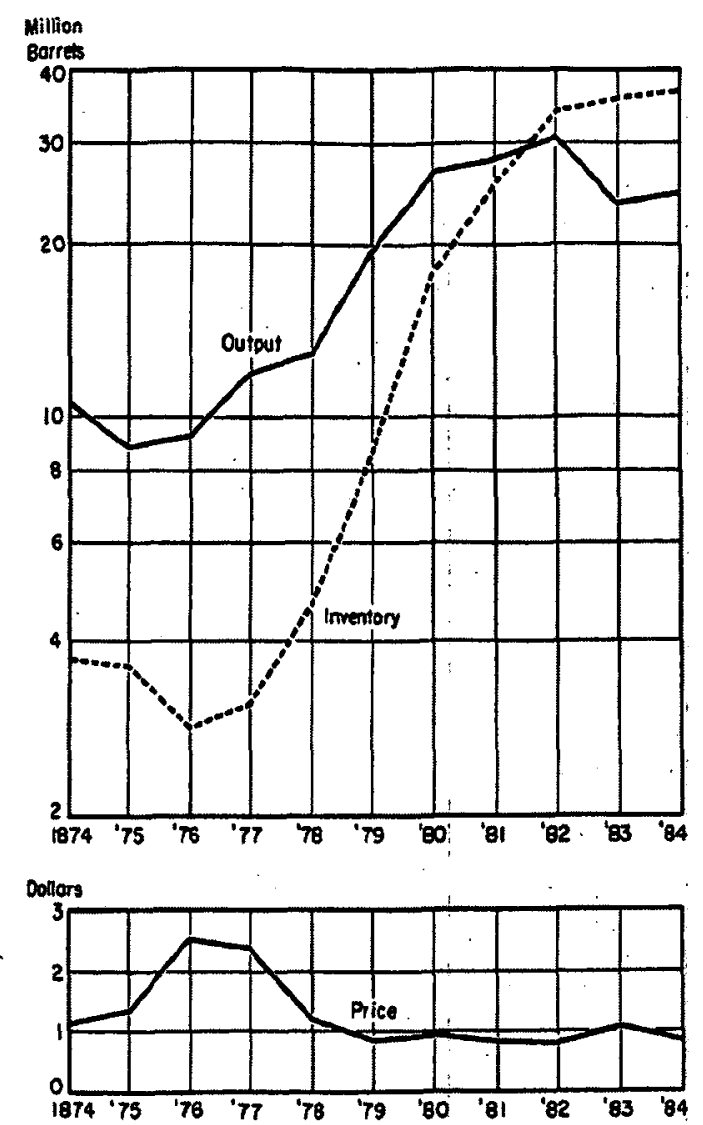

Source: This table is taken from WILlIAMSON \& DAUM, supra note 20, at 373 chart 15:1.

\section{Standard Oil's Monopsony Power over the Railroads}

My belief that Standard Oil exercised monopsony power over the railroads sets forth the sharpest contrast to the Granitz and Klein interpretation that Standard Oil and other refiners propped up a railroad cartel. There is substantial evidentiary support for monopsonization, much of it accepted by Granitz and Klein. As has been discussed, Standard Oil's initial success was through negotiating lower shipment rates by playing off the New York Central Railroad against the Erie Railroad (and Erie Canal) 
with promises of large oil shipments. ${ }^{328}$ Indeed, Standard Oil's emergence as the dominant refiner in Cleveland is best explained on the grounds of the monopsony power that Cleveland's location provided over railroad transport. Standard Oil's subsequent acquisitions of refineries in Pittsburgh extended that power over the Pennsylvania Railroad, and its acquisitions of refineries in West Virginia and Ohio extended that power over the Baltimore \& Ohio Railroad.

In Klein's article published in this Symposium, he repeatedly cites Chernow's conclusion that Rockefeller did not "squeeze" the railroads. 329 But the literature does not support this point. ${ }^{330}$ As discussed, a central ambition of both the National Refiners' Association and the succeeding Central Refiners' Association was to negotiate rates with the railroadssurely lower rates - on behalf of the cartel of refiners. ${ }^{331}$ Williamson and Daum report that by 1874 , Standard Oil possessed a "strong bargaining position" over the railroads; and that in the 1879 New York Hepburn Committee hearings, the Committee Counsel attacked the managers of the trunk railroads "who [had] allowed their roads to become utterly subserviant to Standard Oil's demands.",332

There is more tangible evidence of Standard Oil's monopsony power over the railroads. Beginning with its refinery consolidation in Cleveland in 1872, Standard Oil increasingly integrated vertically into services previously provided by the railroads. In 1872, Standard Oil acquired New York oil docks from the New York Central Railroad; in 1874, Standard Oil also acquired the New Jersey oil terminal facilities of the Erie Railroad. ${ }^{333}$

Over the succeeding years of its national refinery consolidation, it increasingly provided its own tank cars in place of tank cars owned by the railroads. Chernow tells that Standard Oil constructed 600 tank cars for use

328. See supra note 269 and accompanying text.

329. See Klein, supra note 16, at 464 (citing CHERNow, supra note 120, at 113). See also id. at $108,125$.

330. Chernow's book, Titan, is an estimable biography on which I have relied for many points in this Article. Chernow, however, is not an economist, cites no economic literature, and makes economic conclusions that are generally innocent of economic concepts. For example, Chernow says, "[s]o long as he could maintain ample spreads between crude and refined prices, Rockefeller blessed the producers' efforts to impose higher prices and control output." CHERNow, supra note 120, at 159. This statement, however, not only ignores the economic point that higher producer prices even with an "ample" refined oil spread would reduce aggregate demand and reduce a refiner's profits, but also ignores the historical point that both the National and Central Refiners' Associations sought to create refiners' cartels over crude oil purchase to reduce the producers' crude oil prices.

331. See supra notes 307-17 and accompanying text.

332. WILLIAMSON \& DAUM, supra note 20 , at 412,435 .

333. Id. at 413 . 
on the New York Central and Erie railroads. ${ }^{334}$ Williamson and Daum report that Standard Oil put a portion of 520 tank cars on the Erie Railroad, while the Erie Railroad owned only 285 and "was short of cash and credit."335

The railroads were in a difficult position as victims of a monopsony because of their heavy fixed investments. What does a victim of a monopsony do in that position? Certainly, reduce further investments. If the dominant economic power in this industry derived from the cartel of railroads, why would the railroads de-invest by selling terminals and facilities to Standard Oil and allowing Standard Oil to manufacture and own its own tank cars? ${ }^{336}$

There is a further telling episode of Standard Oil's monopsony over the railroads: the Empire Rate War of 1876 and $1877 . .^{337}$ In 1876 , the Pennsylvania Railroad encouraged its New York affiliate, the Empire Transport Company, to acquire previously independent refiners on Long Island and in Philadelphia. ${ }^{338}$ Standard Oil reacted violently. It terminated all refining in Pittsburgh, shifting all oil refining to Cleveland. The Pennsylvania was forced to drastically lower shipment rates to gain customers from producers and the few independent refineries; the New York Central and Erie matched the reductions, engaging in a rate war with the Pennsylvania. ${ }^{339}$ Williamson and Daum report that, despite the decline in rates, oil shipments on the Pennsylvania fell by as much as 52 percent. ${ }^{340}$ The Pennsylvania suspended its dividend, fired hundreds of workers, and reduced worker wages 20 percent, which led to riots and a general strike of railway workers. ${ }^{341}$ Ultimately, the Pennsylvania and Empire Transport Company capitulated and sold to Standard Oil all of the Empire's "refineries, storage tanks, pipelines, a fleet of steamships, tugboats, barges, [and] loading docks."342

334. CHERNOW, supra note 120 , at 201.

335. WILLIAMSON \& DAUM, supra note 20, at 414 .

336. See also CHERNOW, supra note 120 , at 169 ("[T]he railroads shrank from investments in custom-made facilities for handling oil . ..."). This interpretation contrasts with the recent Reksulak and Shughart argument that the railroad shipment discounts to Standard Oil represented compensation for Standard Oil's infrastructure investment. See Reksulak \& Shughart, supra note 23, at 269, 280.

337. Granitz \& Klein, supra note 24, at 28-31. See also WILLIAMSON \& DAUM, supra note 20, at 422-26; CHERNOW, supra note 120, at 201-02 (providing the richest account of the facts).

338. WILLIAMSON \& DAUM, supra note 20, at 423.

339. CHERNOW, supra note 120 , at 201.

340. WILliamson \& DAUM, supra note 20, at 424.

341. CHERNOW, supra note 120 , at 201-02.

342. Id. at 202. 
Granitz and Klein explain the Empire Rate War as an example of "a breakdown in the [South Improvement Company successor] collusive arrangement," $^{343}$ that then was succeeded by another collusive arrangement. According to Granitz and Klein, in this subsequent collusive agreement, Standard Oil again agreed to enforce the railroad cartel, on terms resembling the South Improvement Company, allocating shipment shares among the respective railroads. ${ }^{344}$

There is no doubt that the Empire Rate War constituted a convulsion in the industry. The interesting economic question is why the convulsion occurred the way it did. For example, the episode was not merely a rate war; it was not precipitated by the Pennsylvania Railroad or the Empire Transport Company secretly lowering rates in contravention of an agreement resembling that of the South Improvement Company. The War started when the Pennsylvania Railroad and Empire Transport Company decided to enter refining. Why would the Pennsylvania want to enter refining in competition with Standard Oil whose assumed role was to enforce the railroad cartel? The most plausible economic answer is that there was no railroad cartel; the Pennsylvania was increasingly subjected to the Standard Oil refining monopsony. The Pennsylvania encouraged Empire to enter refining in order to break the Standard Oil monopsony, an explanation totally contrary to Granitz and Klein. Further, as part of its ultimate settlement with Standard Oil, why would a member of a transport cartel sell to Standard Oil principal transport facilities: tugboats, barges, steamships, and especially, pipelines? Again, there is no explanation for these activities consistent with the railroad cartel theory; they are all consistent with the theory that Standard Oil was exercising-again, brutally-its refining monopsony.

This pattern would continue. The Pennsylvania Railroad again attempted to enter oil refining in $1880 .{ }^{345}$ At this point, however, Standard Oil was exerting even further economic pressure on the railroads by its construction of trunk pipelines to the East Coast. ${ }^{346}$ In response, Standard Oil again reduced shipments on the Pennsylvania, leading the Pennsylvania to again capitulate, reaching a settlement in $1881 .{ }^{347}$

343. Granitz \& Klein, supra note 24, at 28.

344. Id. at 29-31.

345. WILLIAMSON \& DAUM, supra note 20, at 451.

346. Id.

347. Id. 


\section{Standard Oil's Monopoly Pricing of Refined Oil}

There is no certain way of measuring the extent of Standard Oil's monopoly power over the price of refined oil. Monopoly pricing is generally presumed from the existence of a monopoly; it is seldom demonstrated. ${ }^{348}$ Over the period, Granitz and Klein show a general decline in both crude oil prices (consistent with monopsony over the producers) and refined oil prices. ${ }^{349}$ The relative differences have not been studied carefully and would be difficult to interpret.

There is some evidence of monopoly prices for refined oil. Williamson and Daum report exports of refined and crude oil over time. ${ }^{350}$ As mentioned, because of the much larger economies in Europe, roughly 75 percent of oil refined in the United States was exported during this period. ${ }^{351}$ There is an important economic question as to why any crude oil was exported. Again, consumer demand was for refined-illuminatingoil, not crude oil. ${ }^{352}$ Given the yields of refined to crude, there must have been a substantial transport cost differential to ship crude to Europe for refining, plus the costs of developing European refineries, rather than to refine it in the United States and ship only the refined. Nevertheless, there were substantial shipments of crude oil during this period, almost all to Europe.

Over the entire time, oil exports increased dramatically. According to Williamson and Daum, exports of refined oil increased from 217 million gallons in 1874, to 332 million gallons in 1879 , to 416 million gallons in $1884 .{ }^{353}$ But there were still, far lower but yet substantial, exports of crude oil: 18 million gallons in 1874; 26 million, in 1879; 67 million, in $1884 .^{354}$

As is evident, European demand for oil increased over this period. It is perhaps reflective of Standard Oil monopoly pricing of refined oil that, of these increases in refined and crude oil, the proportion of crude to refined oil exports increased from 7.8 percent in 1879 to 16.17 percent in $1884 .{ }^{355}$ This suggests that, over this period, the Europeans imported progressively more crude oil than refined, suggesting that Standard Oil was charging

\footnotetext{
348. Though, sometimes, by declining market shares over time.

349. Granitz \& Klein, supra note 24 , at 30 fig. 3.

350. WILLIAMSON \& DAUM, supra note 20, at 742 app. D:1.

351. See supra note 58 and accompanying text.

352. See supra note 59 and accompanying text.

353. WILlIAMSON \& DAUM, supra note 20, at 742 app. D:1.

354. Id.

355. Id.
} 
monopoly prices for refined oil. ${ }^{356}$

\section{CONCLUSION: THE SUCCESS OF THE STANDARD OIL REFINING MONOPOLY RECONSIDERED}

As an economic proposition, the question of which level of production can most effectively monopolize an industry is determined by relative elasticities. Granitz and Klein presume, based upon their conclusion of easy entry into oil refining versus the difficulty of constructing a new trunk railroad from the Oil Regions to the East Coast, that the railroads were in the best position to control the industry; thus, their conclusion that industry control derived from a railroad cartel. ${ }^{357}$ McGee made the same conclusion. ${ }^{358}$

The history here-and the ultimate success of the Standard Oil refining monopoly-shows something different. The producers were unable to cartelize: there were too many of them to support a binding agreement; the best that they could do was to limit new drilling which did not prove effective. Given the lack of central organization, the property rights system - free capture-led to overproduction.

The gathering pipelines were equally unable to form an effective cartel because only a few of them competed against each other. Some of them were able to cut off flow to Standard Oil which encouraged Standard Oil to buy them up to shore up its refining monopoly.

The railroads, though small in number with high costs of entry, could not effectively enforce a cartel agreement because the temptation of taking on extra freight at a rate above marginal cost could not be resisted from a rational economic standpoint. Though there were huge costs of entry against the railroads - and only the modestly competing Baltimore \& Ohio was built during this period, a fact itself that suggests that the railroads were unable to cartelize-the declining cost features doomed cartelization and control over the industry.

Standard Oil, a refiner, not subject to declining average costs and, able to drastically reduce production in order to reduce costs and to monopolize, plus situated in Cleveland allowing it to monopsonize the railroads as well

356. Nevins reports that some European countries subsidized import of crude oil to develop an internal refining industry-important substitution. NEVINS, supra note 19, at 112 . This issue deserves further study.

357. See supra notes 24-30 and accompanying text.

358. See supra note 128 and accompanying text. 
as the producers was able to achieve control over the industry. Its attempts at cartelizing the refining industry failed. Standard Oil bought up competing refineries in a merger-to-monopoly.

In 1911, when the Supreme Court affirmed the dissolution of Standard Oil, it was a different company from the refining monopoly created in the late-1870s. Upon the subsequent discovery of new crude oil sources in Ohio and later in Indiana (later still in Texas), Standard Oil vertically integrated, both into oil production and into oil retailing. Roughly in 1900, the internal combustion engine gained commercial success, vastly increasing the demand for gasoline, as opposed to kerosene, ${ }^{359}$ and enlarging Standard Oil's operations. This vertical integration is not explained in this Article, nor in other economic analyses. It is an interesting economic question why Standard Oil, a successful monopsonist against producers in the Oil Regions, would choose to monopolize production in these newly discovered oil areas. Presumably, the gains from monopsonization were less than the gains from rationalizing oil production, a subject worthy of further study. From an antitrust standpoint, however, the vertical integration and the expansion of the market for refined oils chiefly served to make Standard Oil a larger and more prominent target. That Standard Oil had engaged in various forms of price discrimination, including predatory price discrimination, in its retail sales cemented the verdict against it.

Standard Oil's creation of its refining monopoly in the 1870 s was not then illegal. As shown, in the oil industry, the producers, gathering pipelines, and the railroads had similar intent. Plus, there were wide-scale efforts to cartelize many other industries: tobacco, smelting, matches, copper, sugar, pork, and steel manufacture, among others. All of these efforts would be condemned under the Sherman Act today.

It is curious that the deepest criticism of Rockefeller and Standard Oil over the years has been over the rebates and drawbacks that Standard Oil extracted from the railroads. Tarbell focused her criticism on them, as did the Supreme Court; ${ }^{360}$ even Rockefeller defenders such as Chernow and most remarkably Nevins, whose biographies of Rockefeller are panegyrics, cannot defend the rebates. ${ }^{361}$

359. Edison achieved his Pearl Street, New York demonstration of the effectiveness of electric lighting in 1882, ultimately dooming the kerosene industry, though the extension of commercial application took many years. See NEIL BALDWIN, EDISON: INVENTING THE CENTURY 137-38 (2001).

360. See TARBELL, supra note 13, at 71. See also Standard Oil Co. v. United States, 221 U.S. 1, $42-43$ (1911).

361. See CHERNOW, supra note 120. See also NEVINS, supra note 19. 
In a capitalist economy, it should be expected that buyers will try to secure the best deals from sellers. The railroads, as explained, because of declining average costs, cut rates to optimize shipments. We see the practice, for slightly different economic reasons, in myriad modern situations: clearance sales, end-of-the-year sales, Expedia, Hotwire, and the like. The great American value of equality, however, stands against rebates. During the $1870 \mathrm{~s}$, some states invoked common law principles of fairness and equality to condemn the rebates, claiming that common carriers, like railroads, should be required to serve customers on an equal basis. Later, the Interstate Commerce Act required equality in railroad shipment rates, both generally and, more specifically, in its long-haul, short-haul rule. ${ }^{362}$ The condemnation of Standard Oil for obtaining rebates is in the same tradition. ${ }^{363}$

The success of Standard Oil reveals the imprecision of the legal standard for evaluating claims of monopolization under Grinnell and Trinko. The second factor of the Grinnell test is "(2) the willful acquisition or maintenance of that [monopoly] power as distinguished from growth or development as a consequence of a superior product, business acumen, or historic accident."364 As mentioned, in Trinko, the Court approved monopolization as creating incentives to produce "innovation and economic growth."365

Rockefeller's creation of the Standard Oil refining monopoly surely reflected "business acumen"- - there are volumes of biographies that attest to the fact. That a refiner in Cleveland proved to be in the best position to create a monopoly-because situated at the terminus of two East-bound railroad systems, plus the Erie Canal-might be regarded as "historic accident." It is more difficult to show how the monopoly itself contributed to "innovation," though there were technological innovations in the industry and surely a contribution to "economic growth."

The Grinnell and Trinko standards are too imprecise to carefully address the Standard Oil refining monopoly. The creation of the monopoly would be routinely condemned today. Rockefeller's acquisition of the

362. Interstate Commerce Act of 1887, ch. 104, 24 Stat. 379 (codified as amended in scattered sections of 49 U.S.C.).

363. There is a potentially important historical point here. In the Populist Era, the railroads were viewed as malefactors for giving shipping rebates. Here, at least with respect to oil, the railroads were victims, not malefactors. With respect to oil shipments, it would not be surprising that the railroads supported mandated nondiscrimination laws.

364. United States. v. Grinnell Corp., 384 U.S. 563, 570-71 (1966).

365. Verizon Commc'ns v. Law Offices of Curtis V. Trinko, LLP, 540 U.S. 398, 407 (2004). 
competing Cleveland refiners in 1871 would be blocked; his later acquisition of almost all other refiners nationwide would surely be blocked. And blocked appropriately. John D. Rockefeller possessed many skills, but much of his decisive "business acumen" was directed toward mergers to create a monopoly. Indeed, this history of the oil industry in its early years shows the aggressive means by which firms at all stages of production sought to form cartels to increase prices. The prohibition of cartelization by the Sherman Act, enforced most rigorously against Standard Oil, was necessary to the advance of the American economy. 
